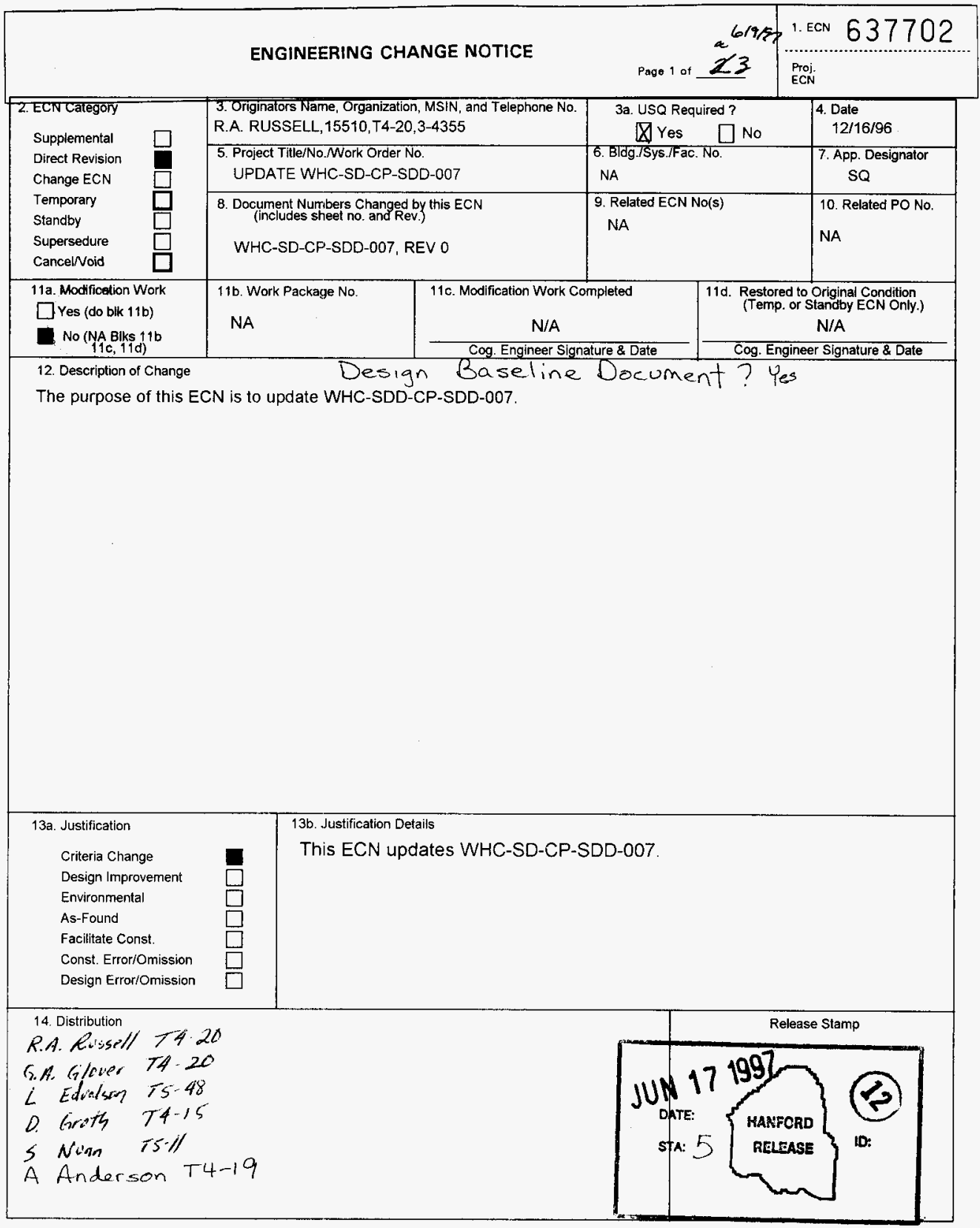


Engineering Change Notice

15. Design

Verification

Required

$\square$ Yes

No
16. Cost Impact

ENGINEERING

$\begin{array}{llll}\text { Additional } & \square & \$ & \\ \text { Savings } & \square & \end{array}$
CONSTRUCTION

$\begin{array}{lll}\text { Additional } & \square & \$ \\ \text { Savings } & \square & \text { N/A }\end{array}$ 637702

17. Schedule Impact (Days)

Improvement

Delay

18. Change Impact Review: Indicate the related docurnents (other than the engineering documents identified on page 1)

That will be affected by the change describe in block 12 . Enter the affected document number in block 19.

\begin{tabular}{|c|c|c|}
\hline SSD/DD & Seismic/Stress Analysis & Tank Calibration Manual \\
\hline Functional Design Criteria & Stress/Design Report & Health Physics Procedure \\
\hline Operating Specification & Interface Control Drawing & Spare Multiple Unit Listing \\
\hline Criticality Specification & Calibration Procedure & Test Procedures/Specification \\
\hline Conceptual Design Report & Installation Procedure & Component Index \\
\hline Equipment Spec. & Maintenance Procedure & ASME Coded Item \\
\hline Constuction Spec. & Engineering Procedure & Human Factor Consideration \\
\hline Procurement Spec. & Operating Instruction & Computer Software \\
\hline Vendor Information & Operating Procedure & Electric Circuit Schedule \\
\hline OM Manual & Operational Safety Requirement & ICRS Procedure \\
\hline FSAR / SAR & IEFD Drawing & Process Control Manual/Plan \\
\hline Safety Equipment List & Cell Arrangement Drawing & Process Flow Chart \\
\hline Radiation Work Permit & Essential Material Specification & Purchase Requisition \\
\hline Environmental Impact Statement & Fac. Proc. Samp. Schedule & \\
\hline Environmental Report & Inspection Plan & \\
\hline Environmental Permit & Inventory Adjustment Request & \\
\hline
\end{tabular}

19. Other Affected Documents: (Note: Documents listed below will not be revised by this ECN.) Signatures below indicate that the signing organization has been notified of other affected documents listed below.

Document Number / Revision Document Number / Revision

Document Number / Revision

WHC-SD-CP-SDD-007, Rev 0

20. Approvals

\section{OPERATIONS and ENGINEERING}

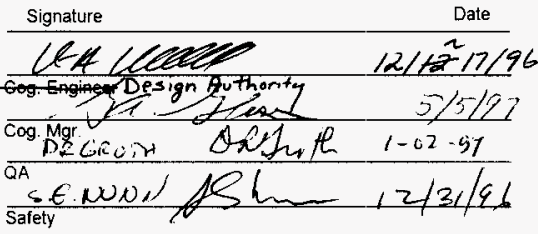

$$
\text { Security }
$$

Environ.

Projects/Program

\begin{tabular}{ll}
\hline Design Eng. Mgr. \\
\hline Indepengent Reviputy
\end{tabular}

Other

\section{ARCHITECT-ENGINEER}

Signature

PE

QA

\begin{tabular}{l}
\hline Safety \\
\hline Design \\
\hline Environ. \\
Other.
\end{tabular}

DEPARTMENT of ENERGY

Signature or a control number that tracks the approval signature. 


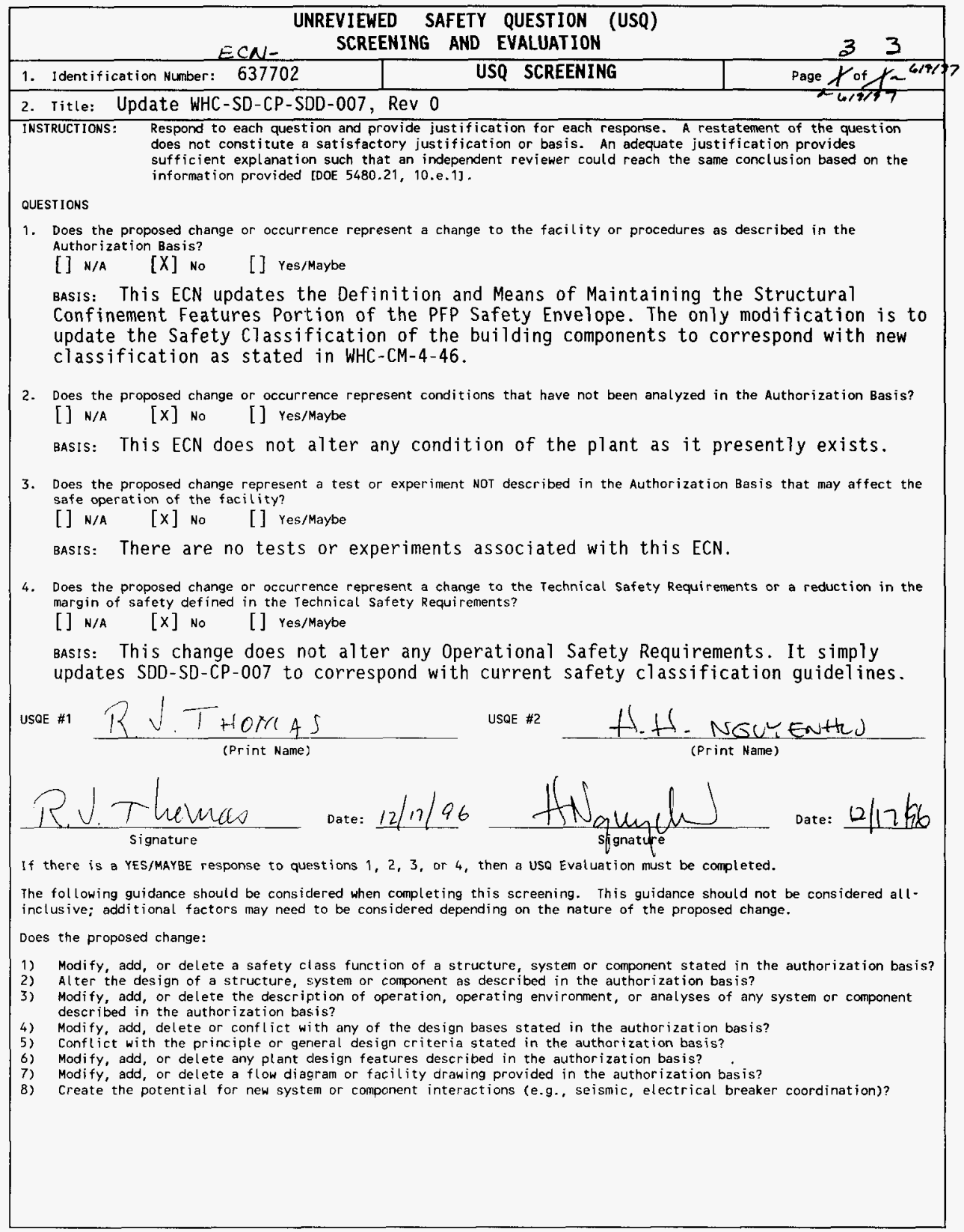

A-6000-615 (10/95) GEF319 


\title{
Definition and Means of Maintaining the Structural Confinement Features Portion of the PFP Safety Envelope
}

\section{R. A. Russe11}

Babcock and Wilcox Hanford Company, Richtand, WA 99352

U.S. Department of Energy Contract DE-ACO6-96RL13200

\author{
EDT/ECN: ECN-637702 UC: 507 \\ Org Code: $15510 \quad$ Charge Code: K6003 \\ B\&R Code: EX70020005ifik7 Total Pages: 77
}

Key Words: Structures, Confinement, Authorization Basis, Safety Envelope

Abstract: This document identifies and documents the justification for the safety classification of the PFP buildings and structures.

IRADEMARK DISCLAIMER. Reference herein to any specific commercial product, process, or service by trade name, trademark, manufacturer, or otherwise, does not necessarily constitute or imply its endorsement, recommendation, or favoring by the United States Goverment or any agency thereof or its contractors or subcontractors.

Printed in the United States of America. To obtain copies of this document, contact: Document Control Services, P.0. Box 950, Mailstop H6-08, Richland WA 99352, Phone (509) 372-2420; Fax (509) 376-4989.

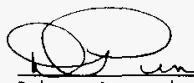

\section{RaD} Release Approval

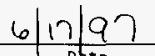

Date

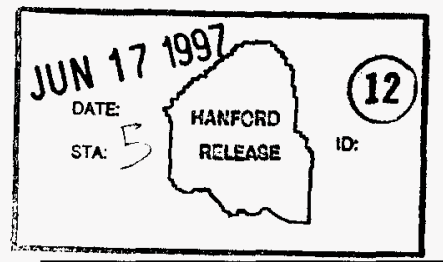

Release Stamp 


\section{RECORD OF REVISION}

(2) Title

DEFINITION AND MEANS OF MAINTAINING THE STRUCTURAL CONFINEMENT FEATURES PORTION OF THE PFP SAFETY ENVELOPE

CHANGE CONTROL RECORD

\begin{tabular}{|c|l|}
\hline (3) Revision & (4) Description of Change - Replace, Add, and Delete Pages \\
\hline 0 & (7) Released by EDT-150989 on 05/19/94 \\
\hline RS Rev 1 & $\begin{array}{l}\text { ECN \# 637702: Reflecting new Safety Class } \\
\text { designations }\end{array}$
\end{tabular}

\begin{tabular}{|l|l}
\hline & \\
\hline &
\end{tabular}

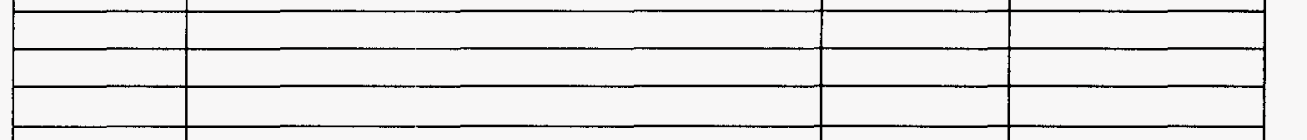




\section{EXECUTIVE SUMMARY}

The buildings and structures of the Plutonium Finishing Plant have been classified in accordance with WHC-CM-4-46, Safety Analysis Manual, Chapter 9.0, "Safety, Structures, Systems, and Components", (WHC 1996) . Six buildings (i.e., 232-Z, 234-5Z, 236-Z, 242-Z, $2736-Z$, and $2736-Z B)$ were found to require classification as Safety Class due to their potential role in mitigating radioactive release to offsite receptors. One structure, 291-Z-1 Stack, was found to be Safety Class due to its potential threat to the other Safety Class buildings. All other buildings and structures are not included in the safety envelope.

\section{REFERENCE}

WHC, I99la, "Safety Classification of Systems, Components, and Structures," Section MRP 5.46, Rev. 4, Management Requirements and Procedures, WHC-CM-1-3, Westinghouse Hanford Company, Richland, Washington.

WHC, 1996, "Safety, Structures, Systems, and Components," Chapter 9.0, Safety Analysis Manual, WHC-CM-4-46, Westinghouse Hanford Company, Richland, Washington. 


\section{CONTENTS}

1.0. PURPOSE . . . . . . . . . . . . . . . . . . . . . . . . . . . 8

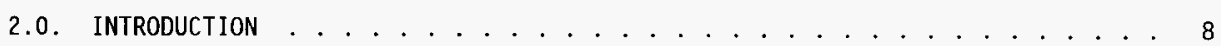

3.0. FACILITY DESCRIPTION . . . . . . . . . . . . . . . . . . . . . . . . 9

4.0. CLASSIFICATION . . . . . . . . . . . . . . . . . . . . . . . . . . 9

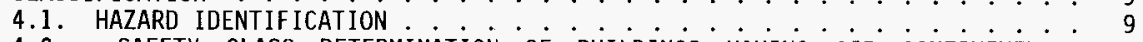

4.2. SAFETY CLASS DETERMINATION OF BUILDINGS HAVING AIR CONFINEMENT FEATURES . . . . . . . . . . . . . . . . . . . . . . . 10

4.3. 291-Z-1 STACK . . . . . . . . . . . . . . . . . . . . . . . . . . . 11

4.4. FACILITIES WITH AIRBORNE HAZARDOUS NON-RADIOACTIVE RELEASE POTÉNTIAL : 11

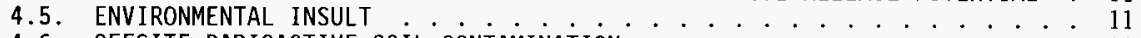

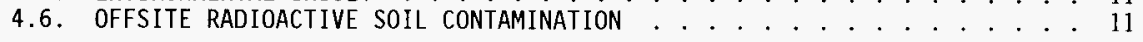

5.0. CONCLUSION . . . . . . . . . . . . . . . . . . . . . . . . . . . . 11

6.0. REFERENCES . . . . . . . . . . . . . . . . . . . . . . . . . . . 13

Appendix A. Safety Classification for Building 291-Z

of the Plutonium Finishing Plant. . . . . . . . . . 14

Appendix B. Airborne Releases of Hazardous Non-Radiological Materials. . . . . . 24

Appendix C. Adverse Environmental Impact From

Non-Radiologically Hazardous Materials in PFP. . . . . . . . 26

Appendix D. Safety Class Determination, Building 241-Z. . . . . . . . . . . . . 33

Appendix E. Structural Components List. . . . . . . . . . . . . . . . . . . . . . 54

$\star \star \star \star * * \star * * * * * * * *$ TRADEMARK NOTES:

1. Krylon Silicon Spray is a Registered Trademark of "DIMC, Inc.".

2. Lectra Clean is a Registered Trademark of "CRC Industries, Inc."

3. LPS is a Registered Trademark of "LPS Laboratories, Inc.".

4. Magnaflux is a Registered Trademark of the "Magnaflux Corporation".

5. Metal Magic is a Registered Trademark of the "Vitachlor Corporation".

6. Weld-On is a Registered Trademark of the "IPS Corporation".

7. ZEP is a Registered Trademark of "NSI Enterprises, Inc.". 


\section{LIST OF FIGURES}

A.1. Building 291-Z and Exhaust Stack 291-Z-1 . . . . . . . . . . . . . . . . . 21

A.2. PFP Ventilation Exhaust System Schematic . . . . . . . . . . . . . . 22 


\section{LIST OF TABLES (Page 1 of 2)}

A.1. Multiplying Factors for Quantity and Half-Life Considerations . . . . . . . . 16

A.2. Total Quantity of Radioactive Materials Released . . . . . . . . . . . . . 17

A.3. Depth to Aquifer . . . . . . . . . . . . . . . . . . . . . . . . . 17

A.4. Distance to Sensitive Surface Waters . . . . . . . . . . . . . . . . . . . 18

A.5. Distance to Offsite Boundary . . . . . . . . . . . . . . . . . . . . 18

A.6. Dose Consequences for a $0.60 \mathrm{~g}$ Release . . . . . . . . . . . . . . . . . . 19

C.1. Environmental Threat Worksheet . . . . . . . . . . . . . . . . . . . . . . 28

E.1. Structurat Components . . . . . . . . . . . . . . . . . . . . . . 59

E.2. 234-5Z Building, First Floor . . . . . . . . . . . . . . . . . . . . . . 60

E.3. 234-5Z Duct Level . . . . . . . . . . . . . . . . . . . . . . . . . 63

E.4. 234-5Z Mezzanine Level ........................... 64

E.5. 234-5Z Mezzanine Level, Column 12 to Column 19 Mezzanine . . . . . . . . . 65

E.6. 234-5Z Building, Second Floor . . . . . . . . . . . . . . . . . . . . . 66

E.7. 234-5Z Building, Roof . . . . . . . . . . . . . . . . . . . . . . 67

E.8. 234-5Z Building, Foundation and Tunnels . . . . . . . . . . . . . . . . . . 68

E.9. 236-Z Building, First Floor . . . . . . . . . . . . . . . . . . . . . 69

E.10. 236-Z Building, Second Floor . . . . . . . . . . . . . . . . . . . . 70

E.11. 236-Z Building, Third Floor . . . . . . . . . . . . . . . . . . . . 71

E.12. 236-Z Building, Fourth Floor . . . . . . . . . . . . . . . . . . . . . 72

E.13. 236-Z Building, Fifth Floor . . . . . . . . . . . . . . . . . . . 73

E.14. 236-Z Building, Sixth Floor ......................... . 73

E.15. 2736-ZB Building, First Floor ....................... . 74

E.16. 2736-Z Building ............................. 74 


\section{LIST OF TABLES (Page 2 of 2)}

E.17. 242-Z Building . . . . . . . . . . . . . . . . . 75

E.18. 291-Z-1 Stack ....................... 76

E.19. 232-Z Building . . . . . . . . . . . . . . . . 76

E.20. 232-Z Building, Second Floor.................. 76 


\subsection{PURPOSE}

The purpose of this document is to define the Safety Envelope (SE) for the Plutonium Finishing Plant (PFP) Structures. The SE is derived from information in of WHC-SD-CP-SAR-021, Plutonium Finishing Plant Final Safety Analysis Report (PFP FSAR), as well as the various natural phenomena hazard analyses.

Implementation of the PFP FSAR requires that the safety envelope for the facility be identified and controlled to ensure the facility is maintained and operated within the established safety envelope. To meet this requirement, this document--together with its appendixes and supplemental documents--provides the following:

- Safety classification of structures (Section 3 and appendixes)

- Safety envelope boundaries (Appendix E)

- Functional and survivability requirements for individuat safety envelope components (Appendix E)

- The procedure for maintaining the safety envelope boundaries (covered by WHC-SD-CP-IP-004, Inspection Procedure and Drawing Configuration Control for Essential Structural Components of Safety $C l a s s ~ 1$ Structures at the Plutonium Finishing Plant (PFP) Complex).

\subsection{INTRODUCTION}

Safety classification is a methodology used to rank all plant systems, structures, and components with respect to their impact on personnel, public, and environmental safety. Safety class guidelines are found in U.S. Department of Energy (DOE) Order 6430.1A (DOE 1989) and implemented at the Hanford Site utilizing WHC-CM-1-3, Management Reguirements and Procedures, Section MRP 5.46, "Safety Classification of Systems, Components, and Structures" (WHC 1991C). WHC-CM-4-46, Safety Analysis Manual, Chapter 9.0, "Safety, Structures, Systems, and Components", (WHC 1996) is currently used for classifying buildings. During a Safety Class determination, the effect of an unmitigated accident in any plant system, structure, or component is analyzed. Consideration for such an accident would include the inherent hazards associated with the facility based on material inventory, material form, and method of dispersion. The safety classification is then determined by the maximum potential exposure to an offsite or onsite receptor. The radiation exposure is measured in rem (roentgen equivalent man) for the effective dose equivalent (EDE) and then compared to the Safety Class criteria.

DOE Order 6430.1A, Section 1300-3, "Safety Class Criteria," provides stringent guidelines for all D0E facilities that have the potential to create a hazard to the public, environment, or worker (DOE 1989). These guidelines distinguish between "Safety Class" items and "non-Safety Class" items. Safety class items are generally defined in DOE Order 6430.1A as those systems, components, and structures for which failure could adversely affect the environment or the safety and health of the public. Non-Safety Class items are generally defined as those systems, components, and structures for which failure will have no significant impact on the environment or the safety and health of the public. 
Westinghouse Hanford Company (WHC) established a Safety Class policy that emulates the DOE Safety Class system guidelines.

This evaluation was conducted for the purpose of assigning safety classes to all PFP structures.

\subsection{FACILITY DESCRIPTION}

PFP was originally constructed in 1949 to concentrate and refine plutonium for use in both weapons and later for reactor fuel. Major buildings covered by this safety classification include the following: 232-Z, the Contaminated Waste Recovery Process Building; 234-5Z, PFP; 236-Z, the Plutonium Reclamation Facility; 241-Z, the Waste Treatment Facility; 242-Z; 291-Z, the Exhaust Fan House; 291-Z-1, the Exhaust Fan Stack; 2736-Z, the Plutonium Storage Facility (PSF); 2736-ZA, the PSF Emergency Diesel Generators and Exhaust Fans; and 2736-ZB, the Product Shipping and Receiving Facility. These structures are shown on drawing $\mathrm{H}-2-80249$, "Room and Door Numbers, ". Other buildings are support buildings and are not otherwise listed in this document.

\subsection{CLASSIFICATION}

The safety classification is determined using the procedure detailed in WHC-CM-446, Safety Analysis Manua7, Chapter 9.0, "Safety, Structures, Systems, and Components", (WHC 1996).

\subsection{HAZARD IDENTIFICATION}

The hazards to the PFP structures include operational/industrial accidents, natural phenomena, and non-operational accidents. Operational/industrial accidents include process accidents, criticalities, fires, gas explosions, and vehicle accidents. The natural phenomenon hazards include earthquakes, wildfires, severe winds, severe rain, and snow or ash fall. The non-operational accidents would include such items as aircraft crashing into the buildings.

The PFP FSAR shows that an aircraft collision is not credible. Also, due to the clear zones in between and on both sides of the security fences, a wildfire poses no credible threat to the facility. 
Therefore, the following hazards are considered:

- Severe wind

- Earthquakes

- Fires (both internal and roof)

- Criticalities

- Internal accidents/upsets

- Flood/severe rain

- Heavy snow/ash fall.

These hazards, and the function codes given to the structural components that mitigate these hazards, are discussed in Appendix E.

\subsection{SAFETY CLASS DETERMINATION OF BUILDINGS HAVING AIR CONFINEMENT FEATURES}

Buildings built for plutonium processing and storage have air confinement features. These buildings include 232-Z, 234-5Z, 236-Z, 241-Z, 242-Z, 291-Z, 2736-Z, 2736-ZA, and 2736-ZB. (See Appendix A for the 291-Z evaluation and Appendix $D$ for the 241-Z evaluation).

Due to the quantity of plutonium stored or processed in 232-Z, 234-5Z, 236-Z, $2736-Z$, and $2736-Z B$, a totally unmitigated accident would cause an offsite dose of greater than 25 rem EDE; thus, these buildings are assigned a safety classification of Safety Class. In accordance with WHC-CM-4-46, Safety Analysis Manual, Chapter 9.0, "Safety, Structures, Systems, and Components", (WHC 1996), this results in a requirement for one Safety Class barrier. A re-evaluation is then performed, assuming maximum credible failure of the Safety Class and non-safety systems. This re-evaluation is the PFP FSAR analysis. Additional information on the consequences of failure of components is contained in WHC-SD-C084-RA-001 (WHC 1991b). These two documents determine that the maximum credible release from $234-52$ is $28 \mathrm{~g}$ of respirable plutonium, which results in 2.9 rem EDE offsite and 7.0 rem EDE onsite (this assumes the exhaust fans continue to run per reference WHC 1991a, paragraph 9.22.4A.7.4).

Assuming the loss of Safety Class and non-safety systems, the maximum credible release for Building $236-Z$ is 11.0 rem EDE onsite and 0.5 rem EDE offsite. Thus, only one Safety class barrier is required.

The PFP FSAR also states that there will be no credible releases of significance from buildings $2736-Z$ or $2736-Z B$ (WHC 1991a). Thus, any additional barriers are nonsafety.

Because there is no processing or storage of plutonium in $242-Z$, it will be assumed that an offsite dose of greater than 0.5 rem but less than 25 rem EDE is caused by the release of residual contamination trapped inside the facility. In accordance with WHC-CM-4-46, Safety Analysis Manual, Chapter 9.0, "Safety, Structures, Systems, and Components", (WHC 1996), this results in one barrier being Safety Class and other barriers being non-safety. In the case of $242-Z$, the secondary barrier is the sealant that was applied after the cleanup of the facility. 


\section{DEFINITION AND MEANS OF MAINTAINING THE STRUCTURAL \\ CONFINEMENT FEATURES PORTION OF THE PFP SAFETY ENVELOPE \\ HNF-SD-CP-SDD-007 \\ Rev. 1 \\ Page 11 of 77}

Buildings $241-Z$ and $291-Z$ are addressed in appendixes $C$ and $A$, respectively, and were found to be non-safety.

\subsection{1-Z-1 STACK}

Building 291-Z-1 Stack does not provide an air confinement function. Since the failure (i.e., collapse) of the stack could result in the breach of confinement of 2736-Z, 2736-ZB, or 234-52--all of which are Safety Class--the stack is Safety Class.

\subsection{FACILITIES WITH AIRBORNE HAZARDOUS NON-RADIOACTIVE RELEASE POTENTIAL}

Most materials in the remaining PFP structures are stored in small quantities that would not pose hazards to onsite receptors. Additionally, the inorganic salt solutions and bases do not produce hazardous vapors. The remaining materials do not exceed the Emergency Response Planning Guidelines (ERPG) $2^{1}$ limits proposed by Hanford Environmental Health Foundation (HEHF). See Appendix B.

\subsection{ENVIRONMENTAL INSULT}

The environmental insult was determined to be the simultaneous release of all non-radioactive hazardous liquids in PFP (see Appendix C). The Environmental Hazard Safety Classification (EHSC) was determined to be less than 500,000, equating to Safety Significant.

\subsection{OFFSITE RADIOACTIVE SOIL CONTAMINATION}

The offsite radioactive soil contamination resulting from airborne releases from all buildings other than those that are already Safety Class is small; buildings involved are 241-Z, 291-Z, and 291-Z-1, and 2735. An airborne release in excess of $22.7 \mathrm{~kg}$ (50 1b) of plutonium would be required to exceed the limits imposed by WHC-CM-4-46, Safety Analysis Manual, Chapter 9.0, "Safety, Structures, Systems, and Components", (WHC 1996). The PFP FSAR shows such a release to be incredible.

\subsection{CONCLUSION}

Buildings in the list below have been classified as Safety Class due to the potential release of radioactive material.

\begin{tabular}{c} 
Safety Class Buildings \\
\hline $232-Z$ \\
$234-5 Z$ \\
$236-Z$ \\
$242-Z$ \\
$2736-Z$ \\
$2736-Z B$ \\
291-Z-1 Stack
\end{tabular}

Al1 secondary air confinement barriers are non-safety.

1 ERPG, American Industrial Hygiene Association, Emergency Response Planning Guidelines. 
A detailed breakdown of the safety classification of each structural component of each building is given in Appendix $E$. 


\subsection{REFERENCES}

DOE, 1989, DOE Order 6430.1A, General Design Criteria, U.S. Department of Energy, Washington, District of Columbia.

Hey, B. E. and L. M. Swanson, 1992, "Dose Consequences and Ground Contamination from Unit Release from all Single Shell Tanks," Internal Memo 29250-BEH-92-005, Westinghouse Hanford Company, Richland, Washington.

WHC, 1988, "Selecting Workplaces," Section 5.0, Rev. 0, Radiological Design Manual, WHC-CM-4-9, Westinghouse Hanford Company, Richland, Washington.

WHC, 1989, Design Loads for Facilities, SDC 4.1, Rev. 11, Westinghouse Hanford Company, Richl and, Washington.

WHC, 1991a, Plutonium Finishing P7ant Final Safety Analysis Report, WHC-SD-CP-SAR-021, Rev. 0, Westinghouse Hanford Company, Richland, Washington.

WHC, 1991b, Plutonium Finishing P7ant (PFP) Seismic Upgrades Review, Project C-084, WHC-SD-C084-RA-001, Westinghouse Hanford Company, Richland, Washington.

WHC, 1991c, "Safety Classification of Systems, Components, and Structures," Section MRP 5.46, Rev. 4, Management Requirements and Procedures, WHC-CM-1-3, Westinghouse Hanford Company, Richland, Washington.

WHC, 1991d, "Safety Classifications," Section EP-1.4, Rev. 1, Standard Engineering Practices, WHC-CM-6-1, Westinghouse Hanford Company, Richland, Washington.

WHC, 1996, "Safety, Structures, Systems, and Components," Chapter 9.0, Safety Analysis Manual, WHC-4-46, Westinghouse Hanford Company, Richland, Washington. 


\section{Appendix A. Safety Classification for Building 291-Z of the Plutonium Finishing Plant.}

\section{A. 1 SUMMARY}

For determination of the safety classification of PFP's Building 291-Z, a conservative and realistic approach is taken. Assuming that 0.60 grams of the estimated plutonium within the plenum is dispersed during a bounding, unmitigated accident, and considering the discussion within this document, the safety classification for Building 291-Z is as follows.

$$
\begin{aligned}
& \text { Environmental Safety Classification }=\text { Safety Class } 3 \\
& \text { Biological Safety Classification }=\text { Safety Class } 3
\end{aligned}
$$

\section{A.2 SITE DESCRIPTION}

Building 291-Z is the main exhaust plenum and fan house for buildings 234-5Z, $242-Z$, and $236-Z$. There are seven electrically-driven exhaust fans and two steamdriven emergency exhaust fans located within 291-Z. In addition, 291-Z houses air compressors, vacuum system equipment in Room 501, and electrical switch-gear in Room 500. Figure A.1 has inore detailed information. Approximately $225,000 \mathrm{cfm}$ of HEPA (high energy particulate air) filtered air moves through 291-Z continuously. This air volume is normally driven with five electric fans, leaving the two remaining fans for system backup during routine maintenance or unit failure (WHC 199la, and Teal and Walters 1988). Figure A.2 depicts $291-Z$ and its physical orientation with respect to related buildings and the 291-Z-1 exhaust stack.

\section{A.3 METHODOLOGY}

Section MRP 5.46, Rev. 4, of WHC-CM-1-3, Management Requirements and Procedures (WHC 1991b), describes the methodology used to determine safety classification. The following analysis is in the format prescribed in that document. Additional data and dispersion information was obtained from SD-CP-ER-019, Rev. 0 (Teal and Walters 1988). A11 tables and data have been reproduced and included herein for clarity and format continuity. 
The analysis methodology outlined in Appendix C of MRP 5.46 (WHC 1991b) involves the following six steps.

1. Assess the form of the material.

2. Determine the multiplying factors for quantity and half-life considerations.

3. Determine the multiplying factors for total quantity of radioactive material released.

4. Determine the multiplying factors for proximity to environmental receivers.

5. Multiply all factors together to determine the environmental impact for Safety Classification.

6. Review all other criteria for relevance to the appropriate Safety Class.

\section{A.4 MATERIAL INVENTORY}

From SD-CP-ER-019 (Teal and Walters 1988), the total estimated content of plutonium downstream of the final HEPA filters is 12 grams. This plutonium was theoretically deposited within the plenum due to HEPA filter limitations, filter or seal failures, procedural mistakes during filter replacement, and abrupt air velocity changes.

Two circumstances exist that make release of the estimated 12 grams of plutonium very unlikely.

- First, it is unlikely that 12 grams of plutonium are actually there. The nondestructive assay (NDA) conducted to determine the source term for Building 291-Z was performed on a small section of Filter Box 9AB immediately downstream of the filters (Teal and Walters 1988). The section analyzed is actually located within Building 234-5Z and was expected to be contaminated because of the nature of the processes being filtered. The estimated amount of plutonium within the 291-Z plenum was extrapolated based on the NIJA and the total interior surface area of the plenum (including all of the plenum area located within 234-5Z). This estimating method results in a very high estimate of the quantity of plutonium within Building 291-Z. Also, the portion of the plenum within 234-5Z is expected to have greater contamination because of air velocity changes and its close proximity to the source of contamination. For these reasons, it is very likely that the actual amount of plutonium present is one half or even one third of the estimated 12 grams.

- Second, the plutonium within the duct appears to be in scale or crystalline form and is "adhered tightly and in need of scraping for removal" (Teal and Walters 1988). This form further reduces the quantity of piutonium that can be expected to be released during a bounding, unmitigated accident. 


\section{DEFINITION AND MEANS OF MAINTAINING THE STRUCTURAL \\ CONFINENENT FEATURES PORTION OF THE PFP SAFETY ENVELOPE}

HNF-SD-CP-SDD-007

Rev. 1

Page 16 of 77

From the circumstances described herein, it is assumed that half of the estimated plutonium is actually within Building $291-Z$ and that only $10 \%$ of the actual source term would be released during a catastrophic, unmitigated accident. Therefore, this Safety class analysis is based on a total release of 0.60 grams of plutonium.

\section{A.5 ENVIRONMENTAL SAFETY CLASS DETERMINATION}

\section{A.5.1 Material Form Deterinination}

Is the radioactive material dispersible?

[ ] NO Do not proceed further. The associated systems, components, and structures are Safety $\mathrm{Cl}$ ass 3 .

[X] YES Proceed.

\section{A.5.2 Quantity and Half-Life Considerations}

The matrix shown in Table A.1 provides multiplying factors as a function of the total estimated curie content postulated to be released to the environment from an unmitigated event. These factors also consider the half-lives of the radioactive isotopes that are present.

Table A.1. Multiplying Factors for Quantity and Half-Life Considerations.

\begin{tabular}{|c|c|c|c|}
\hline \multirow{2}{*}{ Amount (Ci) } & \multicolumn{3}{|c|}{ Half-Life } \\
\cline { 2 - 4 } & $<1$ yrs & $1-100$ yrs & $>100$ yrs \\
\hline$<1$ & 1 & 10 & 100 \\
\hline 1 to 1000 & 10 & 100 & 1000 \\
\hline 1000 to $10^{5}$ & 100 & 1000 & 10000 \\
\hline$>10^{5}$ & 1000 & 10000 & 1000000 \\
\hline
\end{tabular}

The number of curies present in $1 \mathrm{~g}$ of $6 \%$ plutonium is presented in WHC-CP-0063-3, Solid Waste Acceptance Criteria (WHC 1991c), and is used below to determine the total activity for $0.60 \mathrm{~g}$ of $6 \%$ plutonium.

$$
0.60 \mathrm{~g} \mathrm{Pu} \times 0.0929 \mathrm{Ci} / \mathrm{g} \mathrm{Pu}=.05574 \mathrm{Ci}
$$

The half-life of ${ }^{239} \mathrm{Pu}$ is 24,400 years. Using these values, the multiplying factor from Table A.l is 100 . All half-lives of the isotopic radio nuclei of plutonium are considered in determining this factor. The half-life value for ${ }^{239} \mathrm{Pu}$ is used because it is the longest and, therefore, the most conservative approach in selecting the factor. 


\section{A.5.3 Total Quantity of Radioactive Material Released}

Table A.2 gives the multiplying factors based on the total quantity of radioactive material released. The stipulated release of 0.60 grams of plutonium has no liquid and therefore a multiplying factor of 1 is assigned.

Table A.2. Total Quantity of Radioactive Materials Released.

\begin{tabular}{||c|c|}
\hline Quantity & Multiplying Factor \\
\hline$\leq 100$ gallons, $380 \mathrm{~L}, 840$ lbs. & 1 \\
\hline 100 to 1000 gallons, etc. & 5 \\
\hline 1,000 to 10,000 gallons, etc. & 10 \\
\hline$\geq 10,000$ & 100 \\
\hline
\end{tabular}

\section{A.5.4 Proximity to Environmental Receivers}

The source term is further modified to take into account factors for the distance from environmental receivers. Three multipliers are developed based upon distance from the aquifer, surface water, and boundaries of the Site.

A.5.4.1 Aquifer. The distance to the aquifer is greater than 150 feet (WHC 1991a). As noted in Table A.3, the multiplying factor is 1 .

Table A.3. Depth to Aquifer.

\begin{tabular}{||c|c|}
\hline Depth to Aquifer $(\mathrm{ft})$ & Multiplying Factor \\
\hline$\geq 150$ & 1 \\
\hline 76 to 150 & 2 \\
\hline 21 to 75 & 5 \\
\hline 0 to 20 & 10 \\
\hline
\end{tabular}


A.5.4.2 Sensitive Surface Water. The distance to sensitive surface water is greater than 2500 feet (WHC 1991a). As shown in Table A.4, there is no applicable multiplying factor.

Table A.4. Distance to Sensitive Surface Waters.

\begin{tabular}{|c|c|}
\hline Distance to Sensitive Surface Water $(\mathrm{ft})$ & Multiplying Factor \\
\hline$>2500$ & N/A \\
\hline$>1000$ to 2500 & 9 \\
\hline 500 to 1000 & 16 \\
\hline 100 to 500 & 20 \\
\hline$<100$ & 25 \\
\hline Direct discharge to surface water & 50 \\
\hline
\end{tabular}

A.5.4.3 Site Boundary. The distance to the nearest offsite boundary is greater than 2500 feet (WHC 1991a). As shown in Table A.5, the multiplying factor is not app Ticable.

Table A.5. Distance to Offsite Boundary.

\begin{tabular}{|c|c|}
\hline Distance to offsite Boundary (ft) & Multiplying Factor \\
\hline$>2500$ & N/A \\
\hline 1000 to 2500 & 5 \\
\hline$<1000$ & 105 \\
\hline
\end{tabular}




\section{A.5.5 Calculation of Environmental Impact for Safety Classification}

Combining all factors identified from tables A.l through A.5, we find an EHSC of 100 based on the following calculation.

EHSC $=(1) *(1) *(100)=100$

From MRP 5.46 (WHC 1991b):

$\mathrm{EHSC} \geq 1,000,000$

EHSC $<1,000,000$ and $\geq 500,000$

EHSC $<500,000$
= Safety Class I

= Safety Class 2

$=\underline{\text { Safety } \mathrm{Class} 3}$

\section{A. 6 BIOLOGICAL SAFETY CLASS DETERMINATION}

\section{A.6.1 DOSE CALCULATIONS}

Dose calculations for a hypothetical release of $10 \mathrm{~g}$ of plutonium are documented in WHC 199la. These calculations are assumed to be from both ground level and through the 291-2-1 exhaust stack. Note that the ingestion pathway was included in the calculation for the $10 \mathrm{~g}$ stack release dose values. Since the methodology in MRP 5.46 (WHC 1991b) states that "the dose from ingestion is not included" in the .5 rem $1 \mathrm{imit}$ to offsite public exposure, a value correction is applied to the offsite dose for the $0.60 \mathrm{~g}$ release. Table A. 6 reveals the dose values for the various circumstances of a $0.60 \mathrm{~g}$ plutonium release. The table is based on a simple ratio of $0.60 / 10$ and includes a stack release dose adjustment produced by removal of the ingestion pathway.

A comparison between Table A.6 and the guidelines of MRP 5.46 (WHC 1991b) reveals that Building 291-Z will be considered Safety Class 3 for biological dose consequences.

Table A.6. Dose Consequences for a $0.60 \mathrm{~g}$ Release. (No Ingestion)

\begin{tabular}{||c|c|c||}
\hline Disposition & Release Parameters & EDE (rem) \\
\hline \multirow{2}{*}{ Onsite } & Ground Level, 0.55 km WNW & $2.58 \mathrm{E}+00$ \\
\cline { 2 - 4 } & 61 meter Stack, km WNW & $1.50 \mathrm{E}-01$ \\
\hline \multirow{2}{*}{ Offsite } & Ground Level, $13.2 \mathrm{~km} \mathrm{WNW}$ & $7.68 \mathrm{E}-02$ \\
\cline { 2 - 4 } & 61 meter Stack, $12.5 \mathrm{~km} \mathrm{~W}$ & $4.71 \mathrm{E}-02$ \\
\hline
\end{tabular}




\section{A.7 CONCLUSION}

From this analysis, the Building 291-Z bounding Safety Class for the release of radioactive materials shall be considered as follows.

$$
\begin{aligned}
\text { Environmental Hazard Safety Classification } & =\underline{\text { Safety Class } 3} \\
\text { Biological Hazard Safety Classification } & =\underline{\text { Safety Class } 3}
\end{aligned}
$$

\section{A. 8 COMMENTS}

This Safety Classification is based on assumptions considered valid by the investigator. The current data on the actual content and form of the plutonium within Building 291-Z is based on an NDA applied to a small area of the plenum. It would be desirable to obtain source term data from a complete NDA of the entire building. There is no real need to do so, however, since the building will withstand the mitigated accident scenario of a DBE as defined and analyzed in WHC-SD-CP-SAR-021 (WHC 1991a).

This analysis is for Building 291-Z only. Any effects to other buildings that use the plenum for ventilation exhaust were not considered in this analysis. It is expected that a catastrophic accident to Building $291-Z$ would destroy all exhaust capacity. If this were to occur and building supply fans were to remain in operation, a ventilation system pressurization could occur (Note: the supply fans are connected to an automatic seismic shutdown system and there is also a manual scram capability). In addition, roof collapse could propagate a pressure wave upstream through the ductwork and into other buildings. Should these conditions occur, radiation workers could be exposed to direct contamination. 

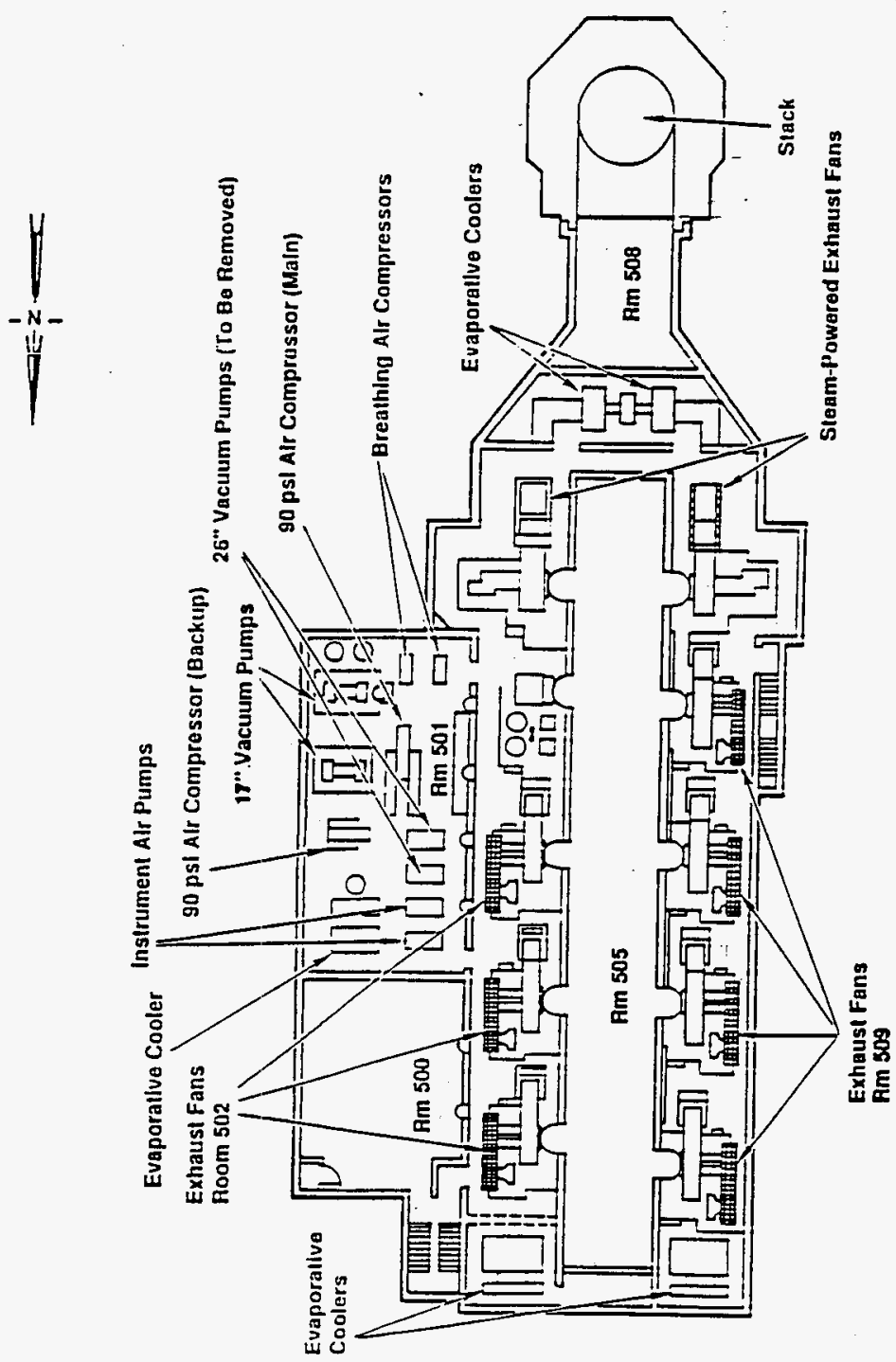

Figure A.1 Building $291-2$ and Exhaust Stack 291-Z-1 


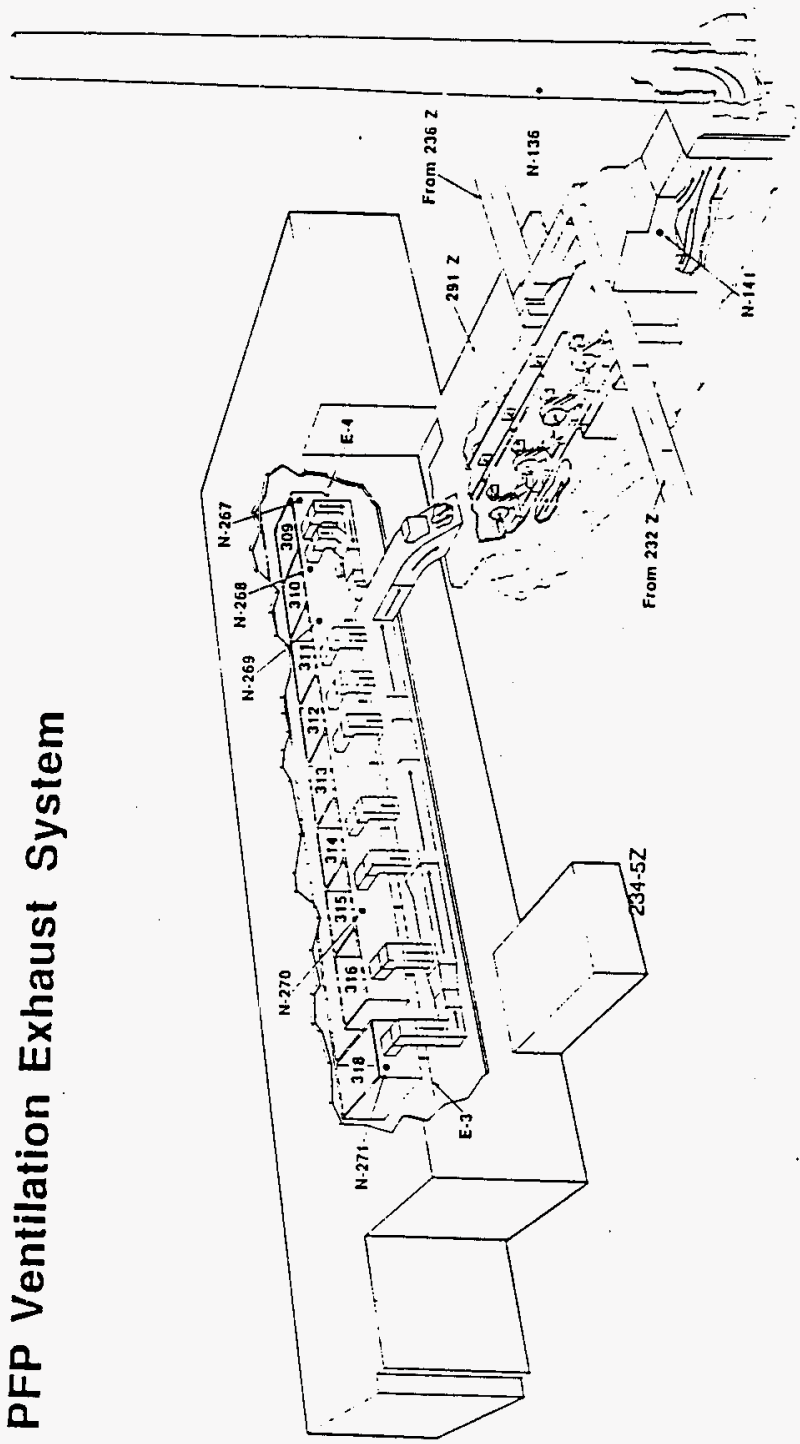

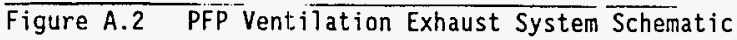




\section{A. 9 REFERENCES}

Teal, J. A. and F. F. Walters, 1988, Review of Plutonium Accumulation in Service Piping and Ductwork Monitoring Enhancement Plan PFP, SD-CP-ER-019, Rev. 0, Westinghouse Hanford Company, Richland, Washington.

WHC, 1991a, Plutonium Finishing Plant Final Safety Analysis Report, WHC-SD-CP-SAR-021, Rev. 0, Westinghouse Hanford Company, Richland, Washington.

WHC, 1991b, "Safety Classification of Systems, Components, and Structures," Section MRP 5.46, Rev. 4, Management Requirements and Procedures, WHC-CM-1-3, Westinghouse Hanford Company, Richland, Washington.

WHC, 1991c, Solid Waste Acceptance Criteria, WHC-CP-0063-3, Westinghouse Hanford Company, Richland, Washington. 


\section{DEFINITION AND MEANS OF MAINTAINING THE STRUCTURAL CONFINEMENT FEATURES PORTION OF THE PFP SAFETY ENVELOPE \\ HNF-SD-CP-SDD-007 \\ Rev. 1 \\ Page 24 of 77}

\section{Appendix B. Airborne Releases of Hazardous Non-Radiological Materials.}

Only a few locations at PFP have sufficient inventories of materials to produce an airborne hazard. These locations are Building 234-5Z, Building 236-Z, Building 2735-Z, and the 241-ZB tanks.

\section{B. 1 BUILDING 234-5Z}

The possible spills of hazardous chemicals and materials were analyzed in FSAR paragraph 9.2.4A.6.3.1.T.6 with the conclusion that there was an insufficient quantity to even approach the ERPG 1 imits, had there been any yet defined (WHC 1991). Hydrogen fluoride (HF) gas is no longer used.

\section{B.2 BUILDING 236-Z}

The possible spills of hazardous chemicals are addressed in FSAR paragraph 9.2.4A.6.3.5 (WHC 1991). The nitric acid ( $\mathrm{HNO}_{3}$ ) and carbon tetrachloride $\left(\mathrm{CC}_{4}\right)$ inventories are smaller than those in the tanks of $2735-\mathrm{Z}$.

\section{B.3 2735-Z AND 241-ZB TANKS}

An analysis of spillage from the $2735-Z$ tanks (aluminum nitrate nonahydrate [ANN], $\mathrm{HNO}_{3}$, and $\mathrm{CCl}_{4}$ ) and Tank $\mathrm{D}-9$ of $241-\mathrm{ZB}$ (sodium hydroxide [ $\left.\mathrm{NaOH}\right]$ ) is presented in the "PFP Hazards Assessment for Non-Radiological Material." The hazards assessment, dated 3 June 92, was prepared by Science Application International Corporation for Westinghouse Hanford Company under contract MDR-SVV-669596, Task \#7 (SAIC 1992).

The airborne ANN, sodium hydroxide $(\mathrm{NaOH})$, and some potassium hydroxide (KOH) are insignificant.

The $\mathrm{HNO}_{3}$ concentration does not exceed the proposed ERPG-2 1 imit of $15 \mathrm{ppm}$ nor the ERPG-3 1 imit of $30 \mathrm{ppm}$ at the nearest receptor, Building 2713-W. At $750 \mathrm{~m}$, this then allows the nitric acid tank and the berm to be Safety class 3 .

As stated in the hazards assessment, the $\mathrm{CCl}_{4}$ tank in the $2735-\mathrm{Z}$ began leaking and was replaced by a 5000 gallon tank on the adjacent truck unloading pad. That tank currently contains approximately 1000 gallons and will be removed when empty. Individual drums will then be utilized. The establishment of the maximum inventory of drums, their storage location, and facilities provided will require further analysis. The current inventory will be used here. 
The truck unloading pad is made of concrete and is 13 feet wide, 34 feet long, and has a one inch berm. The pad has the shape of an inverted pyramid, with the apex being three inches below the bottom of the berm. This pad can contain approximately 550 gallons. On the outside of the berm, there is compacted soil topped with crushed rock. This compacted soil slopes down to a 20-foot-wide blacktop road; the slope is $30 \%$. The horizontal distance from the berm to the road is approximately 10 feet. The far side of the road is sand covered with gravel.

Using the assumptions of the hazards assessment and the Environmental Protection Agency (EPA) method of determining evaporation rate, the evaporation rate was determined. First, the spill area was determined; the $\mathrm{CCl}_{4}$ runs down the slope and across the road with an ever-widening front. The depth (upon soaking in) is $1.0 \mathrm{~cm}$ on the slope and the blacktop and 1.0 inch in the sand and gravel. The size, capacity, and area of each segment is as follows.

- Unloading pad: $13 \mathrm{ft} \times 34 \mathrm{ft}$ rectangle, $551.0 \mathrm{gal}, 442 \mathrm{ft}^{2}$

- Slope: $34 \mathrm{ft}, 40 \mathrm{ft} \times 10.44 \mathrm{ft}$ trapezoid, $94.8 \mathrm{gal}, 386 \mathrm{ft}^{2}$

- Road $40 \mathrm{ft}, 80 \mathrm{ft} \times 20 \mathrm{ft}$ trapezoid, $294.5 \mathrm{gal}, 1200 \mathrm{ft}^{2}$

- Sand: irregular, 59.7 gal, $95.8 \mathrm{ft}^{2}$.

The total area is $442+386+1200+95.8=2123.8 \mathrm{ft}^{2}$ and the evaporation rate is $36.2 \mathrm{lb} / \mathrm{min}=273.6 \mathrm{~g} / \mathrm{s}$. The rate diminishes to approximately one-quarter of this value when the liquid runs off or evaporates from the slope and road, upon which it never was very deep.

Using the methods of FSAR paragraphs 9.2.4A.6.3.5.E and $F$ (except that the evaporation rates were calculated by the EPA method) and assuming a wind speed of $1.0 \mathrm{~m} / \mathrm{s}$, the concentration at the nearest receptor (Building $713-\mathrm{W}, 0.75 \mathrm{~km}$ ENE) is $0.2016 \mathrm{~g} / \mathrm{M}^{3}=201.6 \mathrm{mg} / \mathrm{M}^{3}=32 \mathrm{ppm}$, which is lower than the proposed $\mathrm{CCl}_{4}$ ERPG-2 $1 \mathrm{imit}$ of $50 \mathrm{ppm}\left(314.5 \mathrm{mg} / \mathrm{M}^{3}\right.$ ) and the ERPG-3 $1 \mathrm{imit}$ of $500 \mathrm{ppm}$ (WHC 1991). Thus, the tanks could all be classified as Safety Class 3 with respect to potential airborne contamination.

\section{B.4 REFERENCES}

SAIC, 1992, PFP Hazards Assessment for Non-Radiological Material, Prepared for WHC under Task 7 of Contract MDR-SVV-669596, Science Application International Corporation, Richland, Washington.

WHC, 1991, Plutonium Finishing Plant Final Safety Analysis Report, WHC-SD-CP-SAR-021, Rev. 0, Westinghouse Hanford Company, Richland, Washington. 


\section{DEFINITION AND MEANS OF MAINTAINING THE STRUCTURAL CONFINEMENT FEATURES PORTION OF THE PFP SAFETY ENVELOPE \\ HNF-SD-CP-SDD-007 \\ Rev. 1 \\ Page 26 of 77}

\section{Appendix C. Adverse Environmental Impact From Non-Radiologically Hazardous Materials in PFP.}

The environmental impact from the non-radiologically hazardous materials in the minor buildings of the PFP complex was assessed to determine the Safety Classification. To bound the potential insult, it was assumed that all liquids within the minor buildings were simultaneously released by some non-mechanistic event. Gases, pastes, and solids were excluded because legitimate pathways to potential receivers, aquifers, and sensitive surface waters are not realistic.

First, the material-dependent properties were determined. The inventory of materials was derived from the "Locations Which Have Chemicals Stored in 1991, Area 200W, as of 03/05/92" listing available on Hanford Local Area Network's "Soft

Reporting" application. Pared from this listing are those materials located within the major buildings that are already Safety Class 1 from a radiological hazard standpoint. Fixed tankage was assumed to be full; however, the listing was assumed to be representative of the dynamic inventory of portable containers. For cases in which the same chemical was stored in several locations, the inventories were consolidated for the purposes of this bounding analysis. Inventories of alkanes (i.e., diesel fuel, hydraulic oil, kerosene, mineral oil, motor oil, naphtha, petroleum distillates, soluble oil, and Stoddard's solvent) were consolidated as diesel fuel, which has the major inventory $(5,000 \mathrm{gal})$ of the group. For cases in which a compound was a mixture of several chemicals, the environmental threat of each was determined as if the entire quantity were that chemical; the highest of these was then used as the environmental threat.

Reportable quantities (RQ) for many chemicals are listed in the July 1,1989 revision to 40 Code of Federal Regulations (CFR) 302, Table 302.4 (40 CFR 302, 1989); the source term for these chemicals was determined from the relationship

"S = $10 \times$ Wt/RQ" derived from paragraph 2.a of MRP 5.46, Appendix B (WHC 1991). When no $R Q$ was listed, the source term was determined from paragraph 2.b of MRP 5.46, Appendix B. Next, the EPA carcinogen classification was determined from the Integrated Risk Information System (IRIS) database dated 14 July 1992. If the classification was $A$ or $B$, the carcinogenic multiplying factor was listed as 2.0; otherwise, it was 1isted as 1.0. The individual environmental threats were determined as the product of the source and the carcinogenic multiplying factor. The environmental threats (ET) were then added, for an $\mathrm{ET}_{\text {tot }}=1973.11$. See the "Environmental Threat Worksheet," Table C.l. 
The following factors were used in the analysis:

\begin{tabular}{|c|l|c|}
\hline PARAGRAPH & \multicolumn{1}{|c|}{ ATTRIBUTE } & $\begin{array}{c}\text { MULTIPLICATION } \\
\text { FACTOR }\end{array}$ \\
\hline 3 & $\begin{array}{l}\text { Total Quantity of Material } \\
\text { (Greater Than 10,000 Gallons) } \\
\text { (Conservative Assumption) }\end{array}$ & 100 \\
\hline $4 . a$ & $\begin{array}{l}\text { Distance to Aquifer (Greater Than } \\
\text { 150 Feet) }\end{array}$ & 1 \\
\hline $4 . b$ & $\begin{array}{l}\text { Distance to Sensitive Surface } \\
\text { Waters (Greater Than 2 Miles) }\end{array}$ & 1 \\
\hline $4 . c$ & $\begin{array}{l}\text { Distance to Site Boundary } \\
\text { (Slightly Less Than 10 Miles) }\end{array}$ & 2 \\
\hline
\end{tabular}

The total multiplication factor is $(100)(1)(1)(2)=200$.

The total environmental threat is then the total multiplication factor (200) multiplied by the total from the environmental worksheet (1831.54).

$$
(200)(1831.54)=366,308
$$

This value, 366,308 , is less than 500,000 . Therefore, the chemical storage is Safety Class 3 . 
Table C.1. Environmental Threat Worksheet, Page 1 of 4.

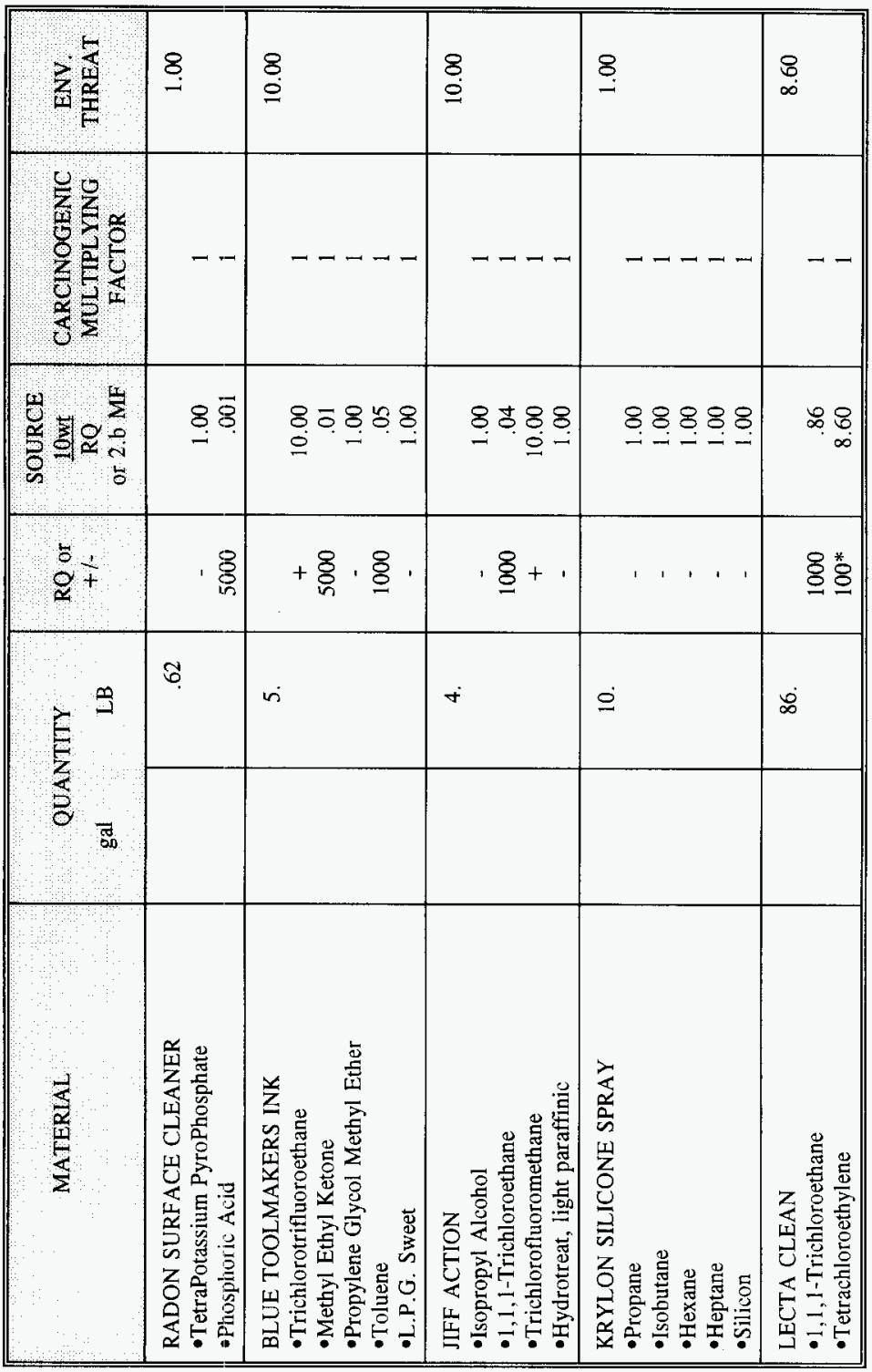


Table C.1. Environmental Threat Worksheet, Page 2 of 4.

\begin{tabular}{|c|c|c|c|c|c|c|c|c|}
\hline $3 \frac{5}{2} \frac{\pi}{\pi}$ & ণ্ণ & $\underset{-}{E}$ & $\stackrel{7}{0}$ & $\stackrel{8}{8}$ & $\stackrel{8}{8}$ & $\stackrel{m}{0}$ & $\delta$ & : \\
\hline 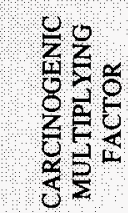 & -- & --- & - & - & --- & -- & - & $\neg--$ \\
\hline$\frac{9}{6}=\stackrel{5}{=}$ & $\begin{array}{ll}\text { 엉요 } \\
0 & 0\end{array}$ & 8 ชే & $\cong$ & $\stackrel{8}{8}$ & 880 & $\widehat{\widehat{0}}$ & ర్రి & ㄱ. \\
\hline$\frac{6}{8}+$ & 8 : & 옹 & 8 & . & , 용 & 8 & 8 & 号号是 \\
\hline \multirow{2}{*}{$\frac{3}{2}_{3}^{\infty}$} & $\stackrel{8}{8}$ & $\begin{array}{l}\underset{E}{E} \\
\underline{-}\end{array}$ & $\stackrel{8}{=}$ & 8 & $\dot{\rho}$ & $\begin{array}{l}\dot{m} \\
\stackrel{2}{2}\end{array}$ & $i$ & $\emptyset^{\prime}$ \\
\hline & & & - & & & i & & \\
\hline$\frac{\frac{b}{a}}{\frac{3}{10}}$ & 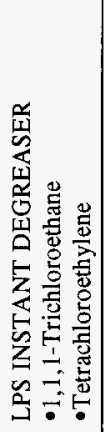 & 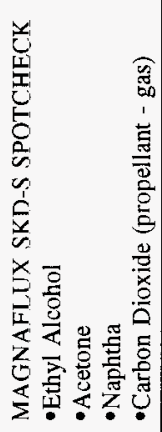 & 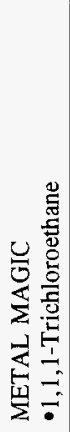 & 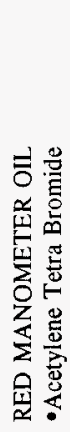 & 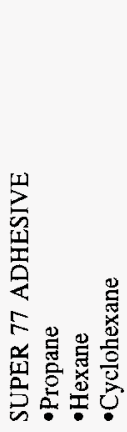 & 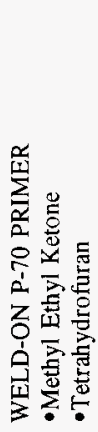 & 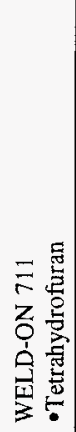 & 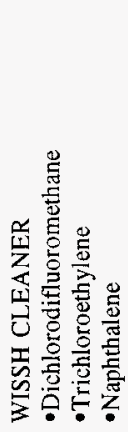 \\
\hline
\end{tabular}


Table C.1. Environmental Threat Worksheet, Page 3 of 4 .

\begin{tabular}{|c|c|c|c|}
\hline$\sum_{i 1} \frac{4}{2}$ & 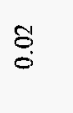 & $\begin{array}{l}8 \\
\dot{+} \\
\dot{\infty}\end{array}$ & 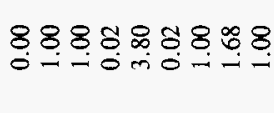 \\
\hline 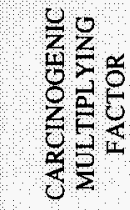 & - & $N-N-T-N-$ & $\neg-\neg-\neg-ー \neg-$ \\
\hline 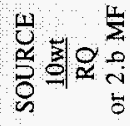 & $\stackrel{5}{0}$ & 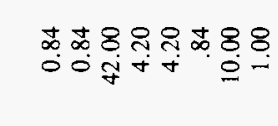 & 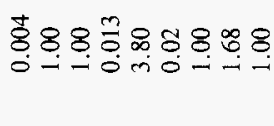 \\
\hline$\frac{2}{0}$ & 只 & 윰윰용용요윰 & 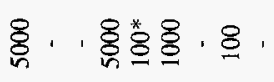 \\
\hline \multirow{2}{*}{$E_{3}^{\infty}$} & $\stackrel{+}{\infty}$ & 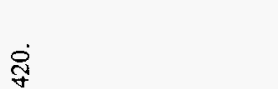 & 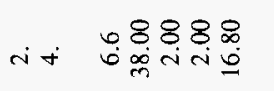 \\
\hline & - & ஜ & - $\quad$ i \\
\hline$\frac{d}{3}$ & 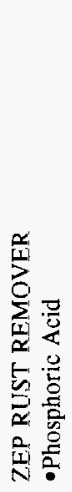 & 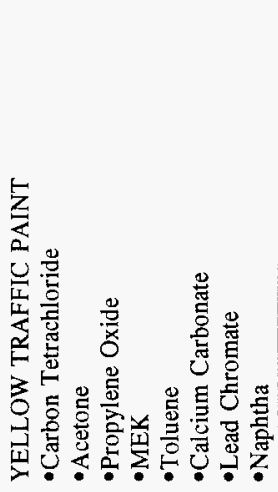 & 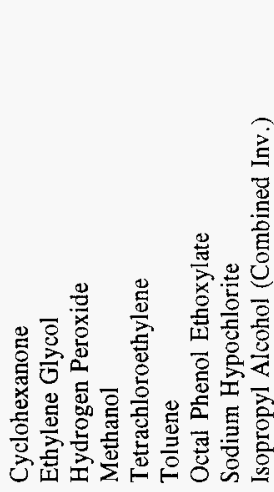 \\
\hline
\end{tabular}


Table C.1. Environmental Threat Worksheet, Page 4 of 4 .

\begin{tabular}{|c|c|}
\hline$\sum_{\underline{4}}^{\frac{5}{4}}$ & 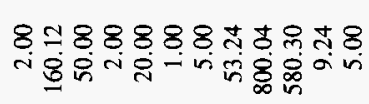 \\
\hline 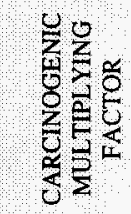 & $\rightarrow-x-m--n----$ \\
\hline 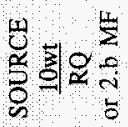 & 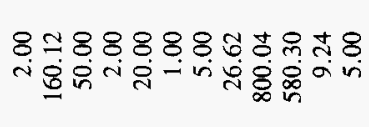 \\
\hline$\frac{5}{a}+$ & 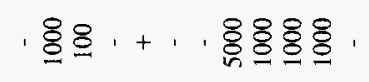 \\
\hline$E^{\circ}$ & 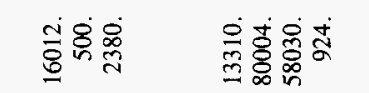 \\
\hline व & 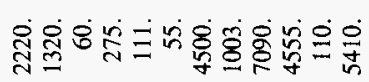 \\
\hline$\frac{3}{\sum}$ & 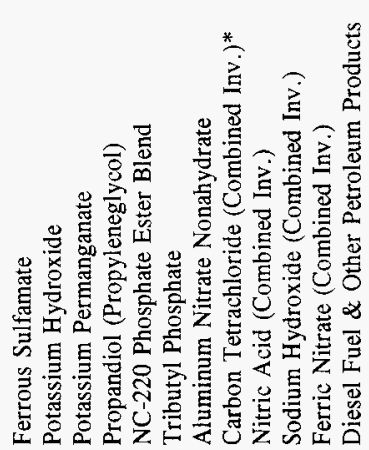 \\
\hline
\end{tabular}




\section{REFERENCES}

40 CFR 302, Title 40, Code of Federal Regulations, Part 302, l July 1989 Revision, Occupational Safety and Health Administration, Washington, District of Columbia.

WHC, 1991, "Safety C1assification of Systems, Components, and Structures," Section MRP 5.46, Rev. 4, Management Requirements and Procedures, WHC-CM-1-3, Westinghouse Hanford Company, Richland, Washington. 


\section{Appendix 0. Safety Class Determination, Building 241-Z.}

From: $\quad$ Systems Safety Analysis

Phone: 3-2065

Date: $\quad$ December 6, 1991

Subject: SAFETY CLASS DETERMINATION, PROJECT C-031H, 241-Z

To:
R. 3. Kidder
H5-36
CC: J. P. Hinckley
R. B. Laws
G. L. Rippy
M. P. Rung
N1-24
T4-10
R3 $3-35$
H5-36

1. DSI, Ron Kidder to Joe Roemer, October 9, 1991, Project C-03IH PSAR Chapter 4 and 9 Analysis/Assessments.

2. Internal Memo, PFP/LAB H\&S 33920-91-093, A. H. Ehlert to J. J. Roemer, Contamination Levels in 241-Z Cel1s, November 14, 1991.

3. Technical Report 11.6 Resuspension of Deposited Aerosols Following Primary system or Containment Failure, Fauske and Associates, Inc., Burr Ridge, IL, August 1984.

4. NUREG/CR-2651, Accident Generated Particulate Materials and The ir Characteristics--A Review of Background Information, S. L. Sutter, May 1982, Pacific Northwest Laboratory, Richland, WA 99352

5. Handbook of Chemistry and Physics, 66th Edition, 1985, R. C. Weast, CRC Press, Inc., Boca Raton, FL

6. NUREG/CR-2139, Aerosols Generated by Free Fall Spills of Powders and Solutions in Static Air, S. L. Sutter, J. W. Johnston, J. Mishima, December 1981, Pacific Northwest Laboratory, Richiand WA 99352

7. WHC-SD-CP-SAR-021, Plutonium Finishing PTant Safety Analysis Report, Draft Submitted to DOE, January 1991, Westinghouse Hanford Company, Richland, WA 99352

8. EPA-520/1-88-020, Limiting Values of Radionuclide Intake And Air Concentration and Dose Conversion Factors For Inhalation. Submersion. and Ingestion, September 1988, United States Environmental Protection Agency, Washingtion DC 20460.

9. DSI, R. B. Laws to J. J. Roemer, Calculations concerning a falling cover block in 241-Z, October 28, 1991. 
10. H-2-87395, Sheet 2 (Preliminary), Process Flow Diagram Waste Neutralization.

11. WHC-CM-1-3, Management Requirements and Procedures, 5.46, Rev 4, August . 28, 1991, Westinghouse Hanford Company, Richland WA 99352

12. H-2-16023, Waste Disposal Facilities Storage Tank Pits, October 1948, General Electric Company, Richland, Washington

13. H-6-951, Hanford Site Map, January 1985, Rockwell Hanford Operations, Richl and, Washirigton 99352

In your DSI you ask that I provide a safety class determination for the 241$Z$ Waste Treatment Facility. I have done this and found that the facility meets the requirements for Safety Class 3 with a very comfortable margin. The dose from airborne release is, in the worst case, $6 \times 10^{-4}$ rem, EDE which is nearly 4 orders of magnitude below the 5 rem threshold and is even below the offsite limit of $0.5 \mathrm{rem}$. Details of the analysis are presented below.

Examination of the details of the analysis show why this rather ordinary designation is applied to this facility: It comes about because the amounts of noxious materials are relatively low, dilute, and the facility is isolated and the material is located below grade. In regard to the underground discharges the site is located on the 200 Area plateau, a long way from both the river, and site boundary and the bottom of the cells are a comfortable distance from the water table. In regard to airborne releases there just is no feasible scenario for dispersal of tank contents and the contamination levels outside the tanks within the cells is too low to create a significant release of airborne material. Contamination levels in the cells will be essentially nonexistent during the installation of the new tanks and for some time afterward. The cells will be cleaned and painted prior to construction. While the cells could then be kept clean more easily there are no plans at this time for regular cell flushes. Therefore the present contamination levels are being used in this analysis because the vaults may, in time, become contaminated to levels approximating the present values.

1. Airborne Release.

Detailed calculations for the airborne release are given in Appendices $A$ and B.

The surface contamination levels in the 241-Z facility have not all been specifically surveyed but are estimated from the levels of contamination found on the protective clothing of workers who have been into the cells and from a survey of parts of one cell (2). The Radiation Protection personnel interviewed (2) feel that there are parts of the cell contaminated to levels of about 2 million disintegrations per minute $(\mathrm{d} / \mathrm{m})$. These levels exist in the lower regions of the cell and on the catwalk. The loose contamination is often found associated with rust in places such as the cat-walk located 
around the tanks at about the $8 \mathrm{ft}$ level. A good share of the contamination is present due to tank overflow occasions that happened over the years. The concrete walls above the cat-walk and top of the tank rather naturally have much less material per unit area than the lower levels. The top of the present $5,000 \mathrm{gal}$ tanks are at about the $9 \mathrm{ft}$ level in an approximately 22 $\mathrm{ft}$ deep cell. The new tanks will have a volume of only about 4,000 gal but the outside surface area will be slightly larger because the tanks will be off the floor so that the bottom is exposed. For the purposes of this analysis, all exterior tank and interior cell surfaces are assumed to be contaminated to the same level of $2-m i l l i o n d / m$. The only energy source for dispersion of this material, as it relates to this project, would be from a seismic event with subsequent falling 6 -in. thick cover-blocks and collapsing walls. In actuality the walls are going to be reenforced to meet Uniform Building Code (UBC) requirements and will handle the forces of an earthquake specified for a Safety Class 2 facility. The tanks would very likely not leak. However, collapse of the cells and leakage of the tanks is assumed for this determination.

Any plutonium bearing materials deposited on the interior surfaces of cells and exterior surfaces of the tanks originated as liquid or as mists. Some may exist as a result of airborne spread of dried material but none of the contamination was originally in the form of dry powders. The atmosphere in the cells is often very damp due to steam condensate from use of steam jets. Materials deposited as solution or in a wet form tend to adhere tightiy as common experience shows and as discussed in (3, p 8-2). Due to the force of gravity the upper areas of the cell would tend to be enriched in smaller particles. Small particles, however, tend to be able to resist the forces of removal better than larger particles. The major adhesive forces decrease in proportion to the diameter of the particles. The effect of air movement decreases in proportion to the cross sectional area or square of the diameter and accelerative forces decrease in proportion to the mass which is related to the cube of the diameter $(3, \mathrm{C}-2)$.

The chemical form of the Pu on the walls is very likely to be the oxide. Aged nitrates and hydroxides convert to oxide in a equilibrium shift enhanced by radiolysis. Oxygen has such a strong affinity for Pu that bonds loosened by alpha particles or by normal bond vibration allows atmospheric oxygen to replace the nitrate, hydroxide or carbonate radicals. These room temperature oxides differ from those formed at elevated temperatures in that they are considered to be soluble in biological fluids such as are found in the nasal and the tracheobronchiolar regions. Thus all material released into the air from $241-2$ will be considered class $W$ and size distribution at the receptor becomes less important. Calculations in appendix $A$ show that only particles with a diameter of less than $10 \mu \mathrm{m}$ will travel to the closest onsite receptor at 272-WA. Fine particies are hard to remove from surfaces specially when applied wet and when it does come off it tends to come off in large flakes. Work cited in reference 3 (page 2-5) as we 11 as experience with cleaning such diverse objects as glovebox interiors and automobiles all offer evidence to this statement. Thus the amount of material with diameters of $510 \mu \mathrm{m}$ is assumed to be on $7 y 10 \%$. 
Two kinds of events are use to determine the dose consequences calculated in Appendix A for suspension of materials on cell and tank surfaces. One model is based on a number of experiments and actual incidents from which resuspension factors were obtained (4). The other model is based on experiments in which containers of powder were upended in a test chamber (6). In all these referenced events the materials involved were dry. Models based on dry material are considered to be conservative since the conditions in the cells are usualiy damp. But the primary component of the dose is contributed by liquid leaking from the tanks.

The tank leak is modeled on the liquid spill experiments in (6). The release fraction is that for a $10 \mathrm{~g} / 1$ uranine solution with a density of 1 $\mathrm{g} / 1$. That is much closer to the density of CAW solution than the $1.7 \mathrm{~g} / 1$ UNH used in other experiments. An additional set of conservatisms exists for all scenarios in that there is only a small chance that the fans would continue to operate and that the filters would be completely non effective following an earthquake large enough to destroy the vaults. Without a mative force there is no way for the material to rise up out of the resulting hole and traveling for $640 \mathrm{~m}$. The particle travel calculations in Appendix $A$ are based on the plume starting at the stack height of $24 \mathrm{ft}$.

Another airborne release considered is one resulting in a release from a pool of very dilute tank contents carried to the surface by water from the broken 2 in. diameter water pipe that services the vaults. Surface spills are often modeled on experiments in which the solution soaked into the ground or was alowed to dry to some extent. With this scenario the water keeps running for the entire $8 \mathrm{~h}$. Thus the release fraction is that for a solute escaping from the forces of surface tension. If it happenes at all it is a very small number. For UNH solution on sandy soil the release rate is given as <1 $\times 10^{-13}\left(8\right.$, Page A.16). The resulting onsite EDE of $<4 \times 10^{-6}$ rem is trivial.

Chemical reactions are not considered in this anatysis as none of them would have enough energy to rupture tanks or the cells. :They are not considered as this project deals only with replacement of tanks and does not envolve the operating equipment or the ventilation system.

\section{Underground Reiease.}

Determination of safety class for subsurface releases is much more simple than for an airborne reiease. The Worksheets in MRP 5.46 (11) provide as rather straightforward approach. The worksheets are included in Appendices $A, B$, and $C$ of this letter. The break point between safety class 3 and safety class 2 is an EHCH score of 500,000. The EHCH score in the worksheets in the case of radioactive discharge is 210,000 which seems rather close to the cutoff but the biggest contributor to this score is the total volume in Part 3 which is shown as greater than 10,000 gal. This comes about because of the assumption that water lines break and that the earthquake does not effect the rest of the water system. The radionuclide concentration is a long way from the break point in Part 2 that would lift 
DEFINITION AND MEANS OF MAINTAINING THE STRUCTURAL CONFINEMENT FEATURES PORTION OF THE PEP SAFETY ENVELOPE
HNF-SD-CP-SDD-007

Rev. 1

Page 37 of 77

the score by another factor of 10 . This kind of a low score is also true in Part 2.a of the non-radiological worksheets.

3. Transfer Lines.

The transfer lines were not specifically considered in this analyst is as the total volume of discharge through these lines would be significantly less than from the entire $241-2$ facility.

4. $236-Z$

Work interfacing with the PRF Facility in Building 236-Z must not compromise the safety class 1 rating of the primary building structure.

\& \& Q berm

J. J. Roemer

Principal Engineer

Attachments: Appendix A, 8-pages

Appendix B, 1-page

Appendix C, 5-pages 


\section{SAFETY CLASS DETERMINATION \\ APPENDIX A \\ PROJECT C-031H, 241-Z \\ CALCULATION OF AIRBORNE DOSE}

Seismically Induced Release of Plutonium-Americium

Volume of Free Space in a Cell

Description of Cell

Length $17 \mathrm{ft}$, Width $17 \mathrm{ft}$., Height $22 \mathrm{ft}$.

Description of Tank (Design not Complete)

Assume: Right cylinder

Diameter $10 \mathrm{ft}$.

Height $8 \mathrm{ft}$.

Volume $($ Free $)=(17 \mathrm{ft} \times 17 \mathrm{ft} \times 22 \mathrm{ft})-\left(3.14 \times 5 \mathrm{ft}^{2} \times 8 \mathrm{ft}\right)=5730 \mathrm{ft}^{3} / \mathrm{cell}^{2}$

$$
\begin{aligned}
& 5730 \mathrm{ft}^{3} \times 0.0283 \mathrm{~m}^{3} / \mathrm{ft}^{3}=162 \mathrm{~m}^{3} / \mathrm{cell} \\
& 162 \mathrm{~m}^{3} \times 1 \times 10^{6} \mathrm{~cm}^{3} / \mathrm{m}^{3}=1.62 \times 10^{8} \mathrm{~cm}^{3} / \mathrm{cell}
\end{aligned}
$$

Surface Area (Exposed in cell, does not include vertical surfaces of grillwork but does assume no holes in grill, includes top and bottom of gri1l and center where the tank is).

Area $=4(17 \mathrm{ft} \times 17 \mathrm{ft})+4(17 \mathrm{ft} \times 22 \mathrm{ft})+2\left(3.14 \times 5 \mathrm{ft}^{2}\right)+(3.14 \times 10 \mathrm{ft} \times 8 \mathrm{ft})=$ $3060 \mathrm{ft}^{2} / \mathrm{ce} 11$

$=3060 \mathrm{ft}^{2} / \mathrm{cell} \times 0.0929 \mathrm{~m}^{2} / \mathrm{ft}^{2}=284 \mathrm{~m}^{2} / \mathrm{ce} 11$

$=284 \mathrm{~m}^{2} / \mathrm{cell} \times 10^{4} \mathrm{~cm}^{2} / \mathrm{m}^{2}=2.84 \times 10^{6} \mathrm{~cm}^{2} / \mathrm{cell}$

Contamination levels assumed to be $2 \times 10^{6} \mathrm{~d} / \mathrm{m} / 100 \mathrm{~cm}^{2}$ on all surfaces. Based on estimates following cell work.

Area contains $2.84 \times 10^{4}, 100 \mathrm{~cm}^{2}$ units/ce11

Thus, total cell surfaces contain

Cel1 surface activity $=2.84 \times 10^{4}\left(100 \mathrm{~cm}^{2}\right.$ units $) / \mathrm{ce} 17 \times 2 \times 10^{6} \mathrm{~d} / \mathrm{m} /\left(100 \mathrm{~cm}^{2}\right.$ unit $)=$ $5.68 \times 10^{10} \mathrm{~d} / \mathrm{m} / \mathrm{cell}$ 


\section{SAFETY CLASS DETERMINATION}

\section{APPENDIX A}

PROJECT C-031H, 241-Z

\section{CALCULATION OF AIRBORNE DOSE}

Grams of Plutonium on Cell Surfaces (The assumption is that the material has the isotopic composition of the material shown in 9.3-5 of WHC-SD-CP-SAR-02. This does not recognize the americium enrichment, but will be used as a first approximation.)

$\frac{5.68 \times 10^{10} \mathrm{~d} / \mathrm{m} / \mathrm{ce} 11}{2.22 \times 10^{12} \mathrm{~d} / \mathrm{m} / \mathrm{ci}} 2.56 \times 10^{-2} \mathrm{ci}_{\alpha} / \mathrm{cell}$ ( $\mathrm{Ci}$ due to alpha activity)

$\frac{2.56 \times 10^{-2} \mathrm{ci} / \mathrm{cel1}}{8.2 \times 10^{-2} \mathrm{ci}_{\alpha} / \mathrm{g}}=3.1 \times 10^{-1} \mathrm{~g} \mathrm{Pu} / \mathrm{cell}$

$\frac{3.1 \times 10^{-1} \mathrm{gPu} / \mathrm{ce} 11}{284 \mathrm{~m}^{2} / \mathrm{ce} 11}=1.1 \times 10^{-3} \mathrm{~g} / \mathrm{m}^{2}$

At least two approaches can be used to approximate (model) the suspension of $\mathrm{Pu}$ from the surfaces. One can use experiments in dropping powders free fall in air. The other uses Resuspension factors from incidents or experiments.

Model as Resuspension ((4)NUREG/CR-2651)

Where $\mathrm{K} / \mathrm{m}=\frac{\text { airborne contamination } / \mathrm{m}^{3}}{\text { surface contamination } / \mathrm{m}^{2}}$

Use: $\mathrm{K} / \mathrm{m}=5 \times 10^{-4} / \mathrm{m}$ (NUREG/CR-2651, page 2.13 , (4) rough average of a number of suspension activities)

$5 \times 10^{-4} / \mathrm{m} \times 1.1 \times 10^{-3} \mathrm{~g} / \mathrm{m}^{2}=5.5 \times 10^{-7} \mathrm{~g} / \mathrm{m}^{3}$

$5.5 \times 10^{-7} \mathrm{~g} / \mathrm{m}^{3} \times 162 \mathrm{~m}^{3} / \mathrm{cell}=8.9 \times 10^{-5} \mathrm{~g} / \mathrm{cell}$ 


\section{SAFETY CLASS DETERMINATION}

\section{APPENDIX A \\ PROJECT C-03IH, 241-Z \\ CALCULATION OF AIRBORNE DOSE}

Calculate particle fallout during plume travel to 272 WA. Distance 241-Z to 272 WA = $640 \mathrm{~m}$

Assume midline plume height = stack height

Assume plume dispersion vertically is trivial compared to $24 \mathrm{ft}$. stack height

(non-conservative) and other uncertainties in analys is

Assume Air Velocity $=1 \mathrm{~m} / \mathrm{sec}(2.2 \mathrm{mi} / \mathrm{h})$

Assume Stability Class = Very Stable (Class $\mathrm{F}$ )

(Air velocity at this low number is associated with conditions of 10 vertical and horizontal movement. Thus, a very tight tube, long thin funnel of air proceeds form the source to the nose of the hypothetical receiver.)

Thus:

$$
\begin{aligned}
& \frac{640 \mathrm{~m}}{1 \mathrm{~m} / \mathrm{s}}=640 \mathrm{~s} \text { of travel to } 272-W A \\
& \text { Stack Height }=24 \mathrm{ft}, 24 \mathrm{ft} \times 30.5 \mathrm{~cm} / \mathrm{ft}=731 \mathrm{~cm} \\
& \frac{731 \mathrm{~cm}}{640 \mathrm{~s}}=1.1 \mathrm{~cm} / \mathrm{s} \begin{array}{l}
\text { (How fast particles must fall to be gone before } \\
\text { reaching } 272-W A)
\end{array}
\end{aligned}
$$

Assume Chemical form is $\mathrm{Pu}$ 0x. A low density oxide formed during alpha disruption of $\mathrm{Pu}\left(\mathrm{NO}_{3}\right)_{4}$ and $\mathrm{Pu}(\mathrm{OH})_{4}$ bonds with air oxygen.

Assume less dense $\left(3 \mathrm{~g} / \mathrm{cm}^{3}\right)$ than fired $\mathrm{PuO}_{2}\left(11.46 \mathrm{~g} / \mathrm{cm}^{3}\right)$ and relatively soluble (Class W).

At a density of $3 \mathrm{~g} / \mathrm{cm}^{3}$, the fall rate will be 3 times that of a density $1 \mathrm{~g} / \mathrm{cm}^{3}$ sphere. Any particle that can fall at $1.1 \mathrm{~cm} / \mathrm{s}$ will be removed from the plume. 


\section{SAFETY CLASS DETERMINATION}

\section{APPENDIX A}

PROJECT C-031H, 241-Z

\section{CALCULATION OF AIRBORNE DOSE}

Application of Stokes Velocity Calculation to determine the size of particles that can travel to 272 WA.

$U_{s}=\frac{g(\rho p-\rho) d^{2}}{18 \mu}$

(3) (5, Page F-102)

Where:

$$
\begin{aligned}
\mathrm{U}_{\mathrm{s}} & =\text { Velocity of the particle, } \mathrm{cm} / \mathrm{s} \\
\mathrm{g} & =\text { acceleration of gravity, } 980 \mathrm{~cm} / \mathrm{s}^{2} \\
\rho \mathrm{p} & =\text { density of the particle, } \mathrm{g} / \mathrm{cm}^{3} \\
\rho & =\text { density of the fluid (For air this is negligible) } \\
\mu & =\text { viscosity of air, poise }=\mathrm{g} / 5 \times \mathrm{cm}=1.82 \times 10^{-4} \mathrm{gm} / \mathrm{s} \mathrm{cm} \\
\mathrm{d} & =\text { diameter of the particle, cm }
\end{aligned}
$$

Rearranging

$\mathrm{d}=\underset{\{\mathrm{g}(\rho \mathrm{p}-\rho)\} 1 / 2}{\left\{18 \mu \mathrm{U}_{\mathrm{S}}\right\}} 1 / 2$

Use: Us $=1.1 \mathrm{crl} / \mathrm{s}$

$$
\rho p=3 \mathrm{~g} / \mathrm{cmB}
$$

Substituting:

$\mathrm{d}=\left[\left.\frac{18 \times 1.82 \times 10-4 \mathrm{~g} / \mathrm{s} \mathrm{cm} \times 1.1 \mathrm{~cm} / \mathrm{s}}{980 \mathrm{~cm} / \mathrm{s} 2 \times 3 \mathrm{~g} / \mathrm{cm} 3}\right|^{1 / 2}=1.1 \times 10-3 \mathrm{~cm}\right.$

$=1.1 \times 10-5 \mathrm{~m}=11 \mu \mathrm{m}$ (microns) Thus all respirable

( $P$ lant pollens range in size from 10 to $100 \mathrm{\mu m} .(5, \mathrm{~F}-238)$. Included for comparison)

Since particles with $d \leq 10 \mu m$ adhere tightly $(3, P 2-5)$ and there is no quantitative information, the result is the following:

Assumption: $10 \%$ of the Pu is resuspended as material with a diameter of $\leq 10 \mu m$.

Resuspension $=8.9 \times 10-5 \mathrm{~g} / \mathrm{cell} \times 0.1=9 \times 10-6 \mathrm{~g}$

Carried to 272-WA for 5 cells $5 \times 9 \times 10-6 \mathrm{~g}=4.5 \times 10-5 \mathrm{~g}$

$$
\text { round to } 5 \times 10.5 \mathrm{~g}
$$




\section{SAFETY CLASS DETERMINATION}

\section{APPENDIX A}

PROJECT C-031H, 241-Z

CALCULATION OF AIRBORNE DOSE

Model as

Dropped Powder ((6) NUREG/CR - 2139)

If all surface material was somehow shaken and blown off by forces resulting from an earthquake, one could model the result on exper jments were powders were dropped fzeefall in a test chamber. The experiments using fine powder of $\mathrm{Tioz}$ with a density of $4.26 \mathrm{~g} / \mathrm{cm}^{3}$ are appropriate ones to use. The

highest percentage of $\mathrm{TiO}_{2}$ made airborne with diameters $\leq 10 \mu \mathrm{m}$ was $0.068 \%$ or 0.00068 fraction $\left(6.8 \times 10^{-4}\right)$

$\mathrm{Pu} / \mathrm{cell}=3.1 \times 10^{-1} \mathrm{~g}$

$3.1 \times 10^{-1} \mathrm{~g} / \mathrm{ce} 11 \times 6.8 \times 10^{-4(<10 \mu \mathrm{m})}=2.1 \times 10^{-4} \mathrm{~g} / \mathrm{ce} 11$

This is highly conservative since there would not be a way to remove all the material as fine powder like that used in the dropping experiments. Thus:

Assume: on 1 y $10 \%$ is shaken loose.

$2.1 \times 10^{-4} \mathrm{~g} / \mathrm{ce} 11 \times 0.1=2 \times 10^{-5} \mathrm{~g}(\leq 10 \mu \mathrm{m}) / \mathrm{ce} 11$

The 24l-Z facility contains 5 cells

$2 \times 10^{-5} \mathrm{~g}(\leq 10 \mu \mathrm{m}) / \mathrm{ce} 11 \times 5=1 \times 10^{-4} \mathrm{~g}(\leq 10 \mu \mathrm{m})$ airborne to $272-\mathrm{WA}$ 


\section{SAFETY CLASS DETERMINATION}

\section{APPENDIX A}

PROJECT C-031H, 241-Z

\section{CALCULATION OF AIRBORNE DOSE}

Using Dose Calculation from (7) WHC-SD-CP-SAR-021

Table 9.3-7 for 6\% 240, Pu, Class W, Ground level release.*

$1 \mathrm{~g}$ release $=5.8 \mathrm{rem}$, EDE or $5.8 \mathrm{rem} / \mathrm{g}$ rounded to $6 \mathrm{rem} / \mathrm{g}$

$1 \times 10^{-4} \mathrm{~g} \times 6 \mathrm{rem} / \mathrm{g}=6 \times 10^{-4}$ (Dropped Powder Mode1)

$5 \times 10^{-5} \mathrm{~g} \times 6 \mathrm{rem} / \mathrm{g}=3 \times 10^{-4} \mathrm{rem}$ (Resuspension Model)

Conclusion: Dose is $\ll 5$ rem. $\therefore$ Safety Class is 3 by this test

* Use of this isotopic mixture rather than one representing the higher Am-241 levels found in 241-Z is justified. Any differences in biological effect between the nuclides are minor ** so different mixtures makes no difference in safety class determination.

** Minor in comparison between $6 \times 10^{-4} \mathrm{rem}$ and $5 \mathrm{rem}$.

EDE $238 \mathrm{Pu}, \mathrm{Class} \mathrm{W} 1.06 \times 10^{-4} \mathrm{~Sv} / \mathrm{Bq}$

EDE $239 / 240 \mathrm{Pu}$, Class $\mathrm{W} 1.16 \times 10^{-4} \mathrm{~Sv} / \mathrm{Bq}$

EDE $241 \mathrm{Am} \mathrm{Class} \mathrm{W} 1.20 \times 10^{-4} \mathrm{~Sv} / \mathrm{Bq}$

EDE $241 \mathrm{PuCl}$ ass $\mathrm{W} 2.23 \times 10^{-6} \mathrm{~Sv} / \mathrm{Bq}$

(8, Table 2.1)

(Beta Emitter) 


\section{SAFETY CLASS DETERMINATION}

\section{APPENDIX A \\ PROJECT C-031H, 241-Z \\ CALCULATION OF AIRBORNE DOSE}

Model as Spilled Liquid (6) Inside Cells

Volume of 1 iquid in tank $=3066 \mathrm{~L}(10)$

Concentration of $\mathrm{Pu}-\mathrm{Am}=0.01 \mathrm{~g} / \mathrm{L}(10)^{*}$

Wt. percent Release as respirable particles (6, Table B-2)

Highest $\%$ for $1 \mathrm{~m}$ spill $=0.00016 \%$ or 0.000016 fraction

$3066 \times 0.01 \mathrm{~g} / \mathrm{L}=31 \mathrm{~g} \mathrm{Pu} / \mathrm{batch}^{*}$

$3066 \mathrm{~L} \times 0.01 \mathrm{~g} / \mathrm{L} \times 0.000016=0.00049 \mathrm{~g} \mathrm{Pu}$ suspended $/$ batch

$$
=4.9 \times 10^{-4} \mathrm{~g}
$$

$0.00049 \mathrm{~g} \mathrm{Pu} \times 6.0 \mathrm{rem} / \mathrm{g} \mathrm{Pu}=0.0029 \mathrm{rem}$

$$
=2.8 \times 10^{-3} \mathrm{rem} / \mathrm{batch}
$$

Only 2 tanks are expected to contain material of this $\mathrm{Pu}$ concentration at any time.

$2.8 \times 10^{-3} \mathrm{rem} /$ batch $\times 2$ batches $=5.6 \times 10^{-3} \mathrm{rem}$

$$
\text { rounded }=6 \times 10^{-3} \mathrm{rem}
$$

* The flowsheet or nominal value for total $\mathrm{Pu}$ is use due to inherent conservatism in modeling. A total of $100 \mathrm{~g} P u / b a t c h$ is a limit imposed in order to meet criticality requirements in Tank Farms. Thus, the nominal value is less than maximum by only a factor of 3 . 


\section{APPENDIX A \\ PROJECT C-031H, 241-Z \\ CALCULATION OF AIRBORNE DOSE}

\section{Surface Liquid}

Assume: Pipe Break during earthquake floods cells and continues for 8 hours bringing essentially all plutonium-bearing solutions to the surface of the ground. No drying taking place as water continues to leak until corrective actions taken. Much of solution would soak into the ground.

Assume: $1 / 2$ to subsurface.

Assume: Al1 5 tanks at $100 \mathrm{~g} \mathrm{Pu} /$ Tank (very conservative)

( $100 \mathrm{~g} /$ TK is a criticality constraint for Tank Farms)

Assume: Pu remains in solution so that it would behave like UNH solutions used in tests (8, Page A.16)

Suspension factor $=<1 \times 10^{-13}$ UNH on sandy soil.

5 Tanks $\times 100 \mathrm{~g} /$ Tank $\times 0.5 \times 4 \times 10^{-13} / \mathrm{sec} \times 60 \mathrm{sec} / \mathrm{min} \times 60 \mathrm{~min} / \mathrm{h} \times 8 \mathrm{~h}$

$=<7.2 \times 10^{-7} \mathrm{~g} \mathrm{Pu}$ suspended round to $<7 \times 10^{-7} \mathrm{~g}$

$<7 . \times 10^{-7} \mathrm{~g} \times 6 \mathrm{rem} / \mathrm{g}=<4 \times 10^{-6} \mathrm{rem}$ 


\section{SAFETY CLASS DETERMINATION \\ APPENDIX B \\ PROJECT C-031, 241-Z \\ MRP 5.46 REV. 4 CALCULATIONS}

Non-radiological

$\mathrm{NaOH}$ (Before CAW Addition)

1. a Yes

b No

2. a Quantity $\mathrm{NaOH}(10)$

$$
\begin{aligned}
5317 \mathrm{lb}(\mathrm{c}) \times 1 / 1000 \times 10 & =53.17 \\
\text { rounded } & =\underline{\underline{53}}
\end{aligned}
$$

3. (Volume) Assume water leak

$$
>10,000 \quad \underline{\underline{100}}
$$

4. a Elevation (MSL) of Bottom of Cell $653 \mathrm{ft}$ (12)

$$
\text { Water Table } \quad \frac{471}{182} \mathrm{ft} \quad(7, \text { Figure } 3.5-7)
$$

$\geq 150 \mathrm{ft} \quad \underline{\underline{1}}$

b Distance to Surface Water (Columbia River)

$6 \mathrm{mi}$

$\underline{\underline{1}}$

c Distance to offsite boundary (7, Page 3-9)

$8 \mathrm{mi} \quad \underline{2}$

5. EPA Carcinogen Class

By Phone: Doug Timmins

$$
\begin{array}{ll}
\mathrm{C}, \mathrm{D} & \underline{\underline{1}} \\
(2 . \mathrm{a})(3 .)(4 . \mathrm{a})(4 . \mathrm{b})(4 . \mathrm{C})(5 .) \\
(53)(100)(1)(1)(2)(1)=10,600
\end{array}
$$

6. $10,600<500,000=$ Safety Class $\underline{\underline{3}}$ 


\section{SAFETY CLASS DETERMINATION \\ APPENDIX C \\ PROJECT C-031H, 241-Z \\ MRP 5.46 CALCULATIONS \\ NON-RADIOLOGICAL}

CAW From H-2-87395 work by C. T. Li Single Tank

\section{1.a Yes}

1.b No

2.a Quantity (1bs) Released

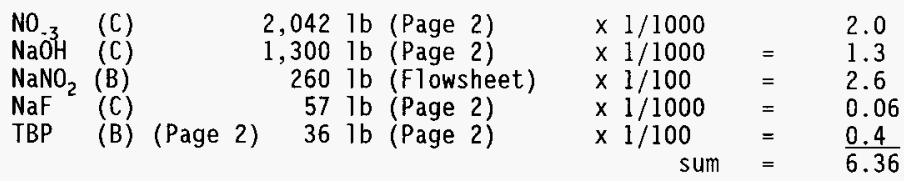

Sum $2 \mathrm{a} 6.36 \times 10=\underline{\underline{64}}$

2.b

\begin{tabular}{lrlr}
$\mathrm{Ca}(\mathrm{OH})_{2}$ & $35 \mathrm{lb}$ & Less (1ight metal) & 1 \\
$\mathrm{Fe}(\mathrm{OH})_{3}$ & $17 \mathrm{lb}$ & Less (see $40 \mathrm{CFR})$ & 1 \\
$\mathrm{Al}(\mathrm{OH})_{3}$ & $369 \mathrm{lb}$ & Less (see $\mathrm{Al}_{2}(\mathrm{SO})_{3}$ in $40 \mathrm{CFR}$ & 1 \\
$\mathrm{Mg}(\mathrm{OH})_{2}$ & $27 \mathrm{~b}$ & Less (1ight metal) & $\frac{1}{4}$ \\
\hline
\end{tabular}

3. Quantity Released/Cel1

$$
\begin{aligned}
& 1339 \text { gal from tank } \quad \text { Mult. Factor }=\underline{\underline{100}} \\
& >10,000 \text { from water leak }
\end{aligned}
$$

4.a Water Table See sheet for $\mathrm{NaOH}$

$$
182 \mathrm{ft} \quad \text { Mult. Factor } \underline{\underline{1}}
$$

4.b Distance to Sensitive Surface Water

Columbia River $6 \mathrm{mi}$ Factor $=\underline{\underline{1}}$

4.c Distance to Offsite Boundary $8 \mathrm{mi}$ Factor $=\underline{\underline{2}}$

5. Carcinogenicity $\quad C, D$ (by Phone from Timmins 10-14-91) Factor $=1$ 
SAFETY CLASS DETERMINATION

APPENDIX C

PROJECT C-031H, 241-Z

MRP 5.46 CALCULATIONS

NON-RADIOLOGICAL

Free $\mathrm{NaOH}$ Determination in Neutralized CAW

Initial $\mathrm{NaOH} \quad 19 \mathrm{M} \times 1581 \mathrm{~L}=30,000$ moles

Subtract due to moles of following Ions Added:

$$
\begin{aligned}
& \mathrm{H}^{+} \quad 2.6 \times 3066 \mathrm{~L}=7972 \text { Moles } \\
& \mathrm{Al}^{+3} .7 \times 3 \times 3066 \mathrm{~L}=6439 \\
& \mathrm{Ca}^{+2} .002 \times 2 \times 3066 \mathrm{~L}=12 \\
& \mathrm{Fe}^{+3} \quad .01 \times 3 \times 3066 \mathrm{~L} \quad 92 \\
& \mathrm{Mg}^{+2} \quad .07 \times 2 \times 3066 \mathrm{~L} \frac{429}{15,056} \\
& 1 \overline{5,056} \text { Moles } \\
& \text { round to 15,000 Moles }
\end{aligned}
$$

$\mathrm{NO}_{3}$ calculate as $\mathrm{HNO}_{3} \quad \frac{2.9 \text { moles } \times 5071 \mathrm{l} \times 63}{453.6 \mathrm{~g} / \mathrm{lb}}=2042 \mathrm{lb}$

15,000 moles $\times 40 \mathrm{~g} / \mathrm{mole}=1,322$ or $1,300 \mathrm{lb}$ assume as free $\mathrm{NaOH}$ $453.6 \mathrm{~g} / 1 \mathrm{~b}$

$\mathrm{NaF} \quad .2 \underline{M} \times 30661=613$ moles

$$
42 \mathrm{~g} / \mathrm{moles} \times 613 \mathrm{moles}=25,746 \quad \frac{25,746}{453.6}=571 \mathrm{~b}
$$

TBP Listed in 40 CFR 302 at 2,4,5 -TP esters

$.02 \mathrm{M} \times 30661=61$ moles

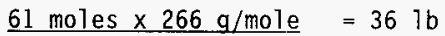
$453.6 \mathrm{~g} / 1 \mathrm{~b}$

$$
\begin{aligned}
& \mathrm{Al}(\mathrm{OH})_{3} \frac{.7 \mathrm{M} \times 3066 \mathrm{l} \times 78 \mathrm{~g} / \mathrm{mole}}{453.6 \mathrm{~g} / 1 \mathrm{~b}}=369 \mathrm{lb} \\
& \mathrm{Ca}(\mathrm{OH})_{2} \frac{.002 \mathrm{M} \times 3066 \mathrm{l} \times 74 \mathrm{~g} / \mathrm{mole}}{453.6 \mathrm{~g} / 7 \mathrm{~b}}=35 \mathrm{lb} \\
& \mathrm{Fe}(\mathrm{OH})_{3} \quad \frac{.014 \mathrm{M} \times 5071 \mathrm{l}}{453.6 \mathrm{~g} / 7 \mathrm{~b}} \times 107 \mathrm{~g} / \mathrm{mole}=17 \mathrm{lb}
\end{aligned}
$$
$\operatorname{Mg}(\mathrm{OH})_{2} \quad \frac{.07 \mathrm{M} \times 30661 \times 58 \mathrm{~g} / \mathrm{mole}}{453.6 \mathrm{~g} / 1 \mathrm{~b}}=27$
6. Calculation: $\mathrm{EHCH}=(2 \mathrm{a}+2 \mathrm{~b})$ (3.) (4.a) (4.b) (4.c) (5)
$(64+4)(100)$ (1) (1) (2) (1) $=13,600$
If $\mathrm{EHCH}=<500,000$ then Class 3
CLA $\overline{S S} \underline{3}$ 


\section{SAFETY CLASS DETERMINATION}

\section{APPENDIX C}

PROJECT C-031H, 241-Z

MRP 5.46 CALCULATIONS

NON-RADIOLOGICAL

$\mathrm{CCl}_{4} \quad \mathrm{CAW}$

1.a Yes

1.b No

2.a From flowsheet prepared by C.T. Li, 10-7-91

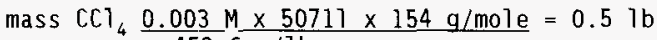
$453.6 \mathrm{~g} / 1 \mathrm{~b}$

Class A $\quad .5 \mathrm{lb} \times 1 / 10=0.05 \mathrm{lb} \times 10=\underline{\underline{.5}}$

2.b N/A

3. $1339 \mathrm{gal}$; water leak $>10,000 \mathrm{gal}$

Mult factor $\underline{\underline{100}}$

4. a

Water Table $182 \mathrm{ft}$ (see $\mathrm{NaOH}$ leak)

Mult. Factor

4.b Distance to sensitive surface water

$\begin{array}{llclr} & \text { Columbia River } 6 \mathrm{mi} & \text { Factor } & \underline{\underline{1}} \\ \text { 4.c } & \text { Distance to offsite boundary } & 8 \mathrm{mi} & \text { Factor } & \underline{\underline{2}} \\ \text { 5. } & \text { Carcinogenicity } & \text { A,B } & \text { Factor } & \underline{\underline{2}} \\ \text { 6. } & \text { Calculation } & & \\ & \text { EHCH }=(2 a+2 b)(3 .)(4 . a)(4 . b)(4 . C)(5) \\ & =(.5)(100)(1)(1)(2)(2)=200 & \\ & \text { If EACH }<500,000 \text { then, Safety ClasS }=3 & \text { SAFETY CLASS 3 }\end{array}$


SAFETY CLASS DETERMINATION

APPENDIX C

PROJECT C-031H, 241-Z

MRP 5.46 CALCULATIONS

NON-RADIOLOGICAL

Radioactive Components

CAW

Typical Isotopic mixture of 5 y age $\mathrm{Pu}$ from WHC-SD-CP-SAR-021

$t_{1 / 2}$ from RHO-RE-SR-2
$\mathrm{t} \frac{1}{2}$
ci $/ \mathrm{g}$

Pu 239

$24,390 y$

$5.79 \times 10^{-2}$

Pu 240

$6580 \mathrm{y}$

$\frac{1.37 \times 10^{-2}}{7.16 \times 10^{-2}} \mathrm{ci} / \mathrm{g}$

sum

$87.6 \mathrm{y}$

$5.11 \times 10^{-3}$

$\mathrm{Pu}-238$

$14.5 y$

$\frac{5.91 \times 10^{-1}}{5.96 \times 10^{-1}} \mathrm{ci} / \mathrm{g}$

Pu 241

Negligible

Pu 242

$432.9 \mathrm{y}$

$3.4 \mathrm{ci} / \mathrm{g}$

Am 241

Trivial

Uranium

Flowsheet Quantities

Pu $\quad 0.009 \mathrm{~g} / 1 \times 30661=27.6 \mathrm{~g}$

$\mathrm{t} \frac{\mathrm{h}}{2}>100 \mathrm{y} ; 7.16 \times 10^{-2} \mathrm{ci} / \mathrm{g} \times 27.6 \mathrm{~g}=1.97 \mathrm{ci}$

If criticality limit is assumed $400 \mathrm{~g}=28.6 \mathrm{ci}$

Factor

$\underline{1000}$

1000

t $\frac{1}{2} 1-100 \mathrm{y} ; 5.96 \times 10^{-1} \mathrm{ci} / \mathrm{g} \times 27.6 \mathrm{~g}=1.6 \times 10^{1} \mathrm{ci}$ Factor

$\underline{100}$ assume criticality limit $\quad 400 \mathrm{~g}=238$

$\underline{\underline{100}}$

Am-241 $\quad 0.001 \mathrm{~g} / 1 \times 30661=3.1 \mathrm{~g}$ assume criticality limit

$45 \mathrm{~g}$

$t \frac{1}{2}>100 y 3.4 \mathrm{ci} / 9 \times 3.1 \mathrm{~g}=10.5 \mathrm{ci}$ assume criticality limit

Factor

$45 \mathrm{~g} \quad 153 \mathrm{ci}$

$\underline{1000}$

Factor Sum $=\underline{2100}$ 


\section{SAFETY CLASS DETERMINATION}

\section{APPENDIX C \\ PROJECT C-03IH, 241-Z \\ MRP 5.46 CALCULATIONS \\ NON-RADIOLOGICAL}

Using criticality spec. does not change the multipliers, even if all 5 tanks were filled to the limits.

CAW

3. Total Material Released (Volume)

1339 gat

water leak increases volume to $>10,000$

Factor $\quad \underline{10} 100$

4. a Depth of Aquifer

$182 \mathrm{ft}$

Factor $\quad \underline{\underline{1}}$

4.b Distance to Sensitive Surface Water

Columbia River $6 \mathrm{mi}, 31680 \mathrm{ft}$

Factor $\quad \underline{\underline{N} / \mathrm{A}}$

4.c Distance to Offsite Boundary

$8 \mathrm{mi}, 42,240 \mathrm{ft}$

$\mathrm{N} / \mathrm{A}$

5. Calculation; (2) (3) (4.a) (4.b) (4.c)

$\mathrm{EHCH}=(2100) \times(100)(1)(\mathrm{N} / \mathrm{A})(\mathrm{N} / \mathrm{A})=210,000$

If $\mathrm{EHCH}<500,000$, then Safety $\mathrm{Class}=3$ 


DEFINITION AND MEANS OF MAINTAINING THE STRUCTURAL
CONFINEMENT FEATURES PORTION OF THE PFP SAFETY ENVELOPE $\begin{array}{r}\text { HNF-SD-CP-SOD-007 } \\ \text { Rev. } 1 \\ \hline\end{array}$

\section{CHECKLIST FOR PEER REVIEW}

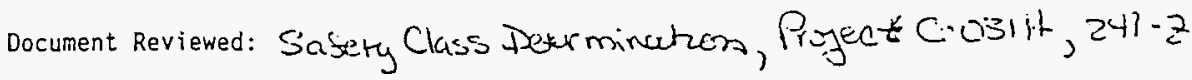

Scope of Review: Check hand calculations

$\frac{\text { Yes No NA }}{[\times][][] *}$

\begin{tabular}{lll}
{$[x]$} & {[]} & {[]} \\
{[]} & {[]} & {$[\times]$} \\
\hdashline$]$ & {[]} & {[]} \\
{[]} & {[]} & {[} \\
{[} & {[]} & {[]} \\
{[]} & {[]} & {[]}
\end{tabular}

(x] [ ] [ ]

X] [ ] [ ]

凶] [ ] [ ]

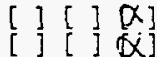

Dis []

$\underset{\alpha}{\infty}]\left[\begin{array}{lll}{[} & {[}\end{array}\right]$

W] [ ] [ ]

[ ] [ ]

Previous reviews complete and cover analysis, up to scope of this review, with no gaps.

Problem completely defined.

Accident scenarios developed in a clear and logical manner.

Necessary assumptions explicitiy stated and supported.

Computer codes and data files documented.

Data useo in calculations explicitly stated in document.

Data checked for consistency with original source information as applicable.

Mathematical derivations checked including dimensional

consistericy of results.

Models appropriate and used within range of validity or use outside range of established validity justified.

Hand calculations checked for errors. Spreadsheet results should be treated exactly the same as hand calculations. Software input correct and consistent with document reviewed. Software output consistent with input and with results reported in document reviewed.

Limits/criteria/guidelines applied to analysis results are appropriate and referenced. Limits/criteria/guidel ines checked against references.

Safety margins consistent with good engineering practices. Conclusions consistent with analytical results and applicable limits.

Results and conclusions address all points required in the problem statement.

Format consistent with appropriate NRC Regulatory Guide or other standards

Review calculations,: comments, and/or notes are attached.

\section{[ ] [ ] Dozument approved.}

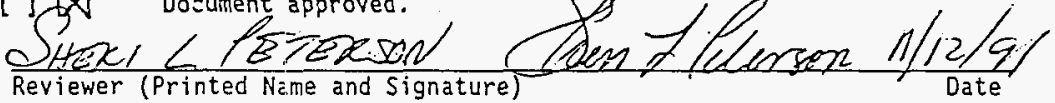

* Any calculations, comments, or notes generated as part of this review should be signed, dated and attached to this checklist. Such material should be labeled and recorded in such a manner as to be intelligible to a technically qualified third party.

[ ] [ ] [ ] Analysis entered into analysis database 


\section{HEDOP REVIEW CHECKLIST for \\ Radiological and Nonradiological Release Calculations}

Document reviewed (include title or description of calculation, document number, author, and date, as applicable):

Sefety class determination, Projeet C-o31 $\mathrm{H}, 241 \mathrm{z}$

Submitted by: J.J. Roomer

Scope of Review: dose calculations Date Submitted: $11 / 25 / 7$ ।

YES NO* N/A

* F [ [ ] [ ] 1. A detailed technical review and approval of the environmental transport and dose calculation portion of the analysis has been performed and documented.

4. [ ] [ ] 2. Detailed technical review(s) and approval(s) of scenario and release determinations have been performed and documented.

4. [ ] [ ] 3. HEDOP-approved code(s) were used.

f7. [ ] [ $]$ 4. Receptor locations were selected according to HEDOP recommendations.

4. [ ] [ ] 5. All applicable environmental pathways and code options

4 [ ] [ ] 6. Hanford site data were used.

Gf [ [] 7. Model adjustments external to the computer program were justified and performed correctly.

D [ ] [ ] 8. The analys is is consistent with HEDOP recommendations.

9. Sufporting notes, calculations, comments, comment resolutions, or other information is attached. (Use the "Page 1 of $X$ " page numbering format and sign and date each added page.)

A [ 10. Approval is granted on behaif of the Hanford Environmental Dose Overview Panel.

* All "NO" responses must be explained and use of nonstandard methods justified.

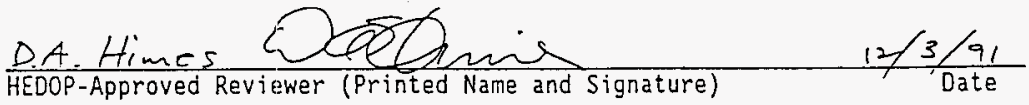

COMMENTS (add additional signed and dated pages if necessary):

* Loses rationd from previous aproved analysis. calculations cheeked ajainst origint l sonrce-ok. 


\section{Appendix E. Structural Components List.}

\section{E.1 INTRODUCTION}

There are seven major credible design basis accidents/events and that the various Safety components perform eight basic functions in order to prevent or mitigate them.

The credible accidents addressed are as follows:

1. A severe wind

2. An earthquake

3. A fire

4. A criticality

5. An internal accident/upset

6. A flood or severe rain

7. A heavy snow or ash fall.

The following should be noted:

1. The numbers that precede the accident/event will be used throughout the discussion of the function codes and are also used in the safety equipment/component tables at the end of this appendix.

2. An internal accident/upset includes all types of process-related accidents/upsets other than criticality; it also includes all industrial accidents.

The eight basic prevention/mitigation functions that the Safety components perform are as follows:

Criticality Prevention

Environmental Protection

Fire Protection

Industrial Health and Safety

Radiation Protection

Structural Support

Internal Compartmentalization

Heating, Ventilation, and Air

Conditioning (HVAC) Zone Boundary
(Function Code C)

(Function Code E)

(Function Code F)

(Function Code I)

(Function Code R)

(Function Code $S$ )

(Function Code $\mathrm{X}$ )

(Function Code $Z$ )

Each of these functions will be addressed, in turn, by this document. Additionally, the typical consequences of the failure of the various components serving these functions is also adidressed. Following the discussion of the various functions, there is a set of tables winch define in detail the exact functions each component performs, which accident it serves to mitigate or prevent, the Safety Class assigned to the component, and the consequences of that component's failure. 


\section{E.2 FUNCTION CODE C: CRITICALITY PREVENTION}

Function Code $C$ is only assigned to those components whose single failure would result in the loss of a redundant safety feature. Typically, this will include all plutonium storage vaults and storage arrays, as well as other components defined in the applicable criticality safety evaluation report (CSER).

The survival code for each of these components is determined by the exact function the component performs. For structural systems, maintaining geometry is the function performed. Thus, the survival codes are as follows.

- The survival code for an earthquake is 2.

- The survival code for a fire is 3 .

- The survival code for a criticality is 4.

- The survival code for an internal accident/upset is 5 .

For storage vaults that are exposed to wind and rain, the following survival codes also apply.

- The survival code for severe wind is 1 .

- The survival code for rain is 6 .

- The survival code for snow is 7.

Failure of a structural component serving a criticality prevention function could cause the loss of a redundant safety feature.

\section{E.3 FUNCTION CODE E: ENVIRONMENTAL CONFINEMENT/PROTECTION}

Function Code $E$ is used to describe those components that perform an environmental confinement or protection function.

For confinement features such as exterior walls and roofs, an environmenta? function requires that the component survive all seven defined accidents/events. These defined accidents/events are as follows:

1. Severe wind, survival code 1

2. Earthquake, survival code 2

3. Fire, survival code 3

4. Criticality, survival code 4

5. Internal accident/upset, survival code 5

6. Severe rain/flood, survival code 6

7. Snow/ash fall, survival code 7.

Failure of a structural component serving an "E" function will result in a breach 
of confinement.

\section{E.4 FUNCTION CODE F: FIRE PROTECTION}

Function Code $F$ is used to describe those structural features that are significant fire mitigating features (even if they are not rated fire barriers) or those that are required by National Fire Protection Association (NFPA 101, 1991) to have a fire rating. Failure of a fire barrier will typically allow a self-propagating fire to spread across the barrier and will allow smoke to migrate throughout the facility. Due to the non-combustible type of construction used throughout the facility, and also due to the facility's fire loading, a self-propagating fire is very unlikely. A smoky fire is possible, however. Thus, special care must be paid to sealing up holes in the fire barriers.

Usually, fire barriers are only required to survive a fire, which is survival code 3. In some special cases such as stairwells, however, they must also survive an earthquake or an internal accident/upset.

\section{E.5 FUNCTION CODE I: INDIJSTRIAL SAFETY/LIFE SAFETY (NFPA 101)}

Although Function Code I may apply to almost every structural component, it is only applied to those components that directly affect life safety. Typically, this is limited to means of egress that would have major impact on facility operations if lost.

The survival codes for these components will vary depending on the accidents to which they are exposed. At a minimum, this will include the following:

- Earthquakes, survival code 2

- Fires, survival code 3

- Criticalities, survival code 4

- Internal accident/upset, survival code 5.

In the case of stair 3 of Building 236-Z, it also includes the following:

- Severe wind, survival code 1

- Snow/ash fall, survival code 7 .

The loss due to these events is credible and would cause unacceptable egress consequences to $236-Z$.

Note that stair 1 of Building $236-Z$ is not included in the discussion of Function Code. I, since that stairway is not a qualified fire escape route.

\section{E.6 FUNCTION CODE R: RADIATION PROTECTION}

Function Code $R$ is typically given to only those components that serve to significantly reduce radiation exposure to facility personnel during day-to-day operations or during a criticality. Because the radiation protection function serves only to mitigate the exposure that facility workers receive from activities and/or an accidental criticality, the only accident these radiation protection components must 
"survive" is a criticality (which has a survival code of 4 )(note that there is no credible way for the criticality to cause the failure of any of the facilities radiation shielding walls). Since the Plant counts on the evacuation of the facility and the distance between the facility and the staging area for radiation protection, the consequence of failure of these components only involves worker radiation exposure. Radiation exposure is to be kept as low as reasonably achievable (ALARA).

\section{E.7 FUNCTION CODE S: STRUCTURAL SUPPORT}

Function code $S$ is given to those building features or components that are relied upon to provide structural support or seismic restraint for the supported system. The primary means for determining the components that perform this structural support function is the structural evaluation. These evaluations may include, but are not limited to, the following: seismic, wind, snow/ash fall, and flood loads, as well as design basis live- and dead-load analysis. In determining the accidents/events that these structural supports must survive, one must consider how the component supports the structure. For example, the concrete shear walls in 234-5Z provide seismic resistance but do not provide resistance to wind loads, while the exterior wall framing does the exact opposite.

In general, all structural support components must survive fire, survival code 3 ; internal accident/upset, survival code 5; and seismic events, survival code 2.

Additionally, all exterior component supports such as roof framing and structural columns must also survive wind, survival code 1; rain, survival code 6; and snow/ash fall, survival code 7 .

Since criticality, with a survival code of 4 , poses no threat to the structures and the structures do not initigate the event, the structures do not have to "survive" a criticality event, although they will and in the case of 234-5Z, have in fact survived such an event. The only structural items that must survive a criticality are those that prevent the criticality from getting worse (i.e., the storage arrays) (note that the arrays used at PFP are steel and will not be affected by a criticality). 


\section{DEFINITION AND MEANS OF MAINTAINING THE STRUCTURAL \\ CONFINEMENT FEATURES PORTION OF THE PFP SAFETY ENVELOPE \\ HNF-SD-CP-SDD-007 \\ Rev. 1 \\ Page 58 of 77}

The consequence of failure of the structures varies from direct environmental release (in the case of 236-Z) to breach of confinement (in the case of 234-5Z) to 1oss of other confinement facilities (in the case of the 291-Z-l Stack). Any of these could result in Safety Class consequences.

\section{E.8 FUNCTION CODE X: INTERNAL COMPARTMENTALIZATION}

Internal Compartmentalization, Function code $X$, is used to describe the boundaries of process or storage areas. Typically, an accident inside these areas is mitigated by the walls, floor, and ceiling of the room. The typical accidents of concern are fire and intermal accident/upset, survival codes 3 and 5 , respectively. In certain specialized cases, however, additional accidents must be addressed.

In areas where a criticality is credible, the compartmentalization also serves to confine the contamination so that the event is much like an internal accident. Thus, a criticality survival code of 4 is assigned (note that the walls, ceilings etc of PFP will survive a criticality). In areas that are specifically named in chapter 9 of the FSAR (WHC 1991) as compartmenting the release due to a seismic event, a seismic survival code of 2 is assigned; these areas are rooms 166 and 227, the Remote Mechanical "C" (RMC) Line, and the Remote Mechanical "A" (RMA) Line.

The consequence of all breaches of internal compartmentation is an internal facility release --that is, contamination is allowed to spread inside the facility. For a scenario in which chapter 9 of the FSAR takes credit for compartmentation as mitigating the release due to a seismic event by confining the release to a specific area of the building, the consequence of failure is a breach of confinement. Breaches of confinement, in turn, lead to potential environmental releases.

\section{E.9 FUNCTION CODE Z: HVAC ZONE BOUNDARY}

Function Code $Z$ is used to describe the structural boundaries of the HVAC zones. Typically, the HVAC zones include the exterior shell of the building; the "front side/back side" boundary; and the HVAC ducts, dampers, and controllers. The purpose of this boundary is to control air flow and to maintain air pressure at the designed set point.

Failure of a zone boundary typically causes a loss of differential pressure between the two zones of the building or between the building and atmosphere. The probable consequence of this loss of differential pressure is a minor internal facility release. code 5.

Typically, a zone boundary must survive only an internal accident/upset, survival 
DEFINITION AND MEANS OF MAINTAINING THE STRUCTURAL

CONFINEMENT FEATURES PORTION OF THE PFP SAFETY ENVELOPE
HNF-SD-CP-SDD-007

Rev. 1

Page 59 of 77

Table E.1. Structural Components

\begin{tabular}{||l|l|l|l|l||}
\hline \multicolumn{1}{|c|}{ BLDGS. } & \multicolumn{1}{|c|}{ COMPONENT } & FUNCTION & $\begin{array}{l}\text { SAFETY CLASS/ } \\
\text { SURVIVAL }\end{array}$ & \multicolumn{1}{|c|}{$\begin{array}{c}\text { CONSEQUENCE } \\
\text { MITIGATED }\end{array}$} \\
\hline \hline ALL & $\begin{array}{l}\text { BLDG. CONSTRUCTION } \\
\text { MATERIAL }\end{array}$ & $\mathrm{F}$ & $\begin{array}{l}\text { Safety } \\
\text { Significant } \\
3\end{array}$ & FIRE SPREAD \\
\hline ALL & COLUMNS & $\mathrm{S}$ & $\begin{array}{l}\text { Safety Class } \\
1,2,3,5,6,7\end{array}$ & $\begin{array}{l}\text { BREACH OF } \\
\text { CONFINEMENT }\end{array}$ \\
\hline ALL & DOORS- EXTERIOR & $\mathrm{E}, Z$ & $\begin{array}{l}\text { Safety Class } \\
1,2,3,4,5,6,7\end{array}$ & $\begin{array}{l}\text { ENVIRONMENTAL } \\
\text { RELEASE }\end{array}$ \\
\hline ALL & $\begin{array}{l}\text { FLOORS, CONCRETE } \\
\text { ABOVE GRADE }\end{array}$ & $\mathrm{S}, \mathrm{X}, \mathrm{F}$ & $\begin{array}{l}\text { Safety Class } \\
2,3,5\end{array}$ & $\begin{array}{l}\text { BREACH OF } \\
\text { CONF INEMENT }\end{array}$ \\
\hline ALL & $\begin{array}{l}\text { FOOTINGS/ } \\
\text { FOUNDATIONS }\end{array}$ & $\mathrm{S}$ & $\begin{array}{l}\text { Safety Class } \\
1,2\end{array}$ & $\begin{array}{l}\text { BREACH OF } \\
\text { CONFINEMENT }\end{array}$ \\
\hline ALL & FRAMING - FLOOR & $\mathrm{S}$ & $\begin{array}{l}\text { Safety Class } \\
2,3,5\end{array}$ & $\begin{array}{l}\text { BREACH OF } \\
\text { CONFINEMENT }\end{array}$ \\
\hline ALL & FRAMING - ROOF & $\mathrm{E}$ & $\begin{array}{l}\text { Safety Class } \\
1,2,3,4,5,6,7\end{array}$ & $\begin{array}{l}\text { ENVIRONMENTAL } \\
\text { RELEASE }\end{array}$ \\
\hline ALL & $\begin{array}{l}\text { FRAMING - } \\
\text { EXTERIOR WALL. }\end{array}$ & $\mathrm{E}$ & $\begin{array}{l}\text { Safety Class } \\
1,2,3,4,5,6,7\end{array}$ & $\begin{array}{l}\text { ENVIRONMENTAL } \\
\text { RELEASE }\end{array}$ \\
\hline
\end{tabular}

NOTE: "AT1" is defined as 236-Z, 242-Z, 234-5Z, 2736-Z, and 2736-ZB 
Table E.2. 234-5Z Building, First Floor (Page 1 of 3 ).

\begin{tabular}{|c|c|c|c|}
\hline COMPONENT & FUNCTION & $\begin{array}{l}\text { SAFETY CLASS/ } \\
\text { SURVIVAL }\end{array}$ & $\begin{array}{l}\text { CONSEQUENCE } \\
\text { MITIGATED }\end{array}$ \\
\hline $\begin{array}{l}\text { EXTERIOR WALLS - EXCEPT } 192 \mathrm{~A}, \mathrm{~B}, \\
\mathrm{C} \text { VAULTS AND OFFICE ANNEX }\end{array}$ & $E, Z$ & $\begin{array}{l}\text { Safety Class } \\
1,2,3,4,5,6,7\end{array}$ & $\begin{array}{l}\text { ENV IRONMENTAL } \\
\text { RELEASE } \\
\end{array}$ \\
\hline $\begin{array}{l}\text { CONCRETE EXTERIOR WALL - } 192 \text { A,B, } \\
\& \text { C VAULTS }\end{array}$ & $E, Z, C, R$ & $\begin{array}{l}\text { Safety Class } \\
1,2,3,4,5,6,7\end{array}$ & $\begin{array}{l}\text { ENV IRONMENTAL } \\
\text { RELEASE, } \\
\text { CRITICALITY }\end{array}$ \\
\hline $\begin{array}{l}\text { INTERIOR WALL - COLUMN LINE C } \\
\text { CONCRETE WALL (C4 TO C21) }\end{array}$ & $S, X, Z, F$ & $\begin{array}{l}\text { Safety Class } \\
2,3,5\end{array}$ & $\begin{array}{l}\text { BREACH OF } \\
\text { CONFINEMENT }\end{array}$ \\
\hline $\begin{array}{l}\text { INTERIOR WALL - COLUMN LINE E } \\
\text { CONCRETE WALL E4 THRU E21 }\end{array}$ & $S, X$ & $\begin{array}{l}\text { Safety Class } \\
2,3,5\end{array}$ & $\begin{array}{l}\text { BREACH OF } \\
\text { CONFINEMENT }\end{array}$ \\
\hline $\begin{array}{l}\text { INTERIOR WALL - COLUMN LINE } 4 \\
\text { CONCRETE WALL (C4 TO E4) }\end{array}$ & $S, x$ & $\begin{array}{l}\text { Safety Class } \\
2,3,5\end{array}$ & $\begin{array}{l}\text { BREACH OF } \\
\text { CONFINEMENT }\end{array}$ \\
\hline CONCRETE WALLS - STAIR 1 & $\mathrm{~S}, \mathrm{I}, \mathrm{F}$ & $\begin{array}{l}\text { Safety Class } \\
2,3,5\end{array}$ & $\begin{array}{l}\text { BREACH OF } \\
\text { CONF INEMENT }\end{array}$ \\
\hline CONCRETE WALLS - STAIR 2 & $S, F, I$ & $\begin{array}{l}\text { Safety Class } \\
2,3,5\end{array}$ & $\begin{array}{l}\text { BREACH OF } \\
\text { CONF INEMENT }\end{array}$ \\
\hline CONCRETE WALLS - ELEVATOR SHAFT & $S, F, X$ & $\begin{array}{l}\text { Safety Class } \\
2,3,5\end{array}$ & $\begin{array}{l}\text { BREACH OF } \\
\text { CONF INEMENT }\end{array}$ \\
\hline $\begin{array}{l}\text { INTERIOR WALL - CEILINGS \& WALLS } \\
\text { OF RM. } 166\end{array}$ & $S, F, R, E$ & $\begin{array}{l}\text { Safety Class } \\
2,3,5\end{array}$ & $\begin{array}{l}\text { BREACH OF } \\
\text { CONF INEMENT }\end{array}$ \\
\hline
\end{tabular}


Table E.2. 234-5Z Building, First Floor (Page 2 of 3).

\begin{tabular}{||l|l|l|l||}
\hline \multicolumn{1}{|c|}{ COMPONENT } & FUNCTION & $\begin{array}{l}\text { SAFETY CLASS/ } \\
\text { SURVIVAL }\end{array}$ & $\begin{array}{l}\text { CONSEQUENCE } \\
\text { MITIGATED }\end{array}$ \\
\hline $\begin{array}{l}\text { INTERIOR WALL - WALLS OF RM. 173, } \\
\text { 174, 175 \& CEILINGS }\end{array}$ & $\mathrm{C}, \mathrm{F}, \mathrm{R}, \mathrm{X}$ & $\begin{array}{l}\text { Safety ClaSS } \\
2,3,4,5\end{array}$ & $\begin{array}{l}\text { CRITICALITY } \\
\text { INTERNAL } \\
\text { FACILITY } \\
\text { RELEASE }\end{array}$ \\
\hline $\begin{array}{l}\text { INTERIOR WALL - WALLS OF RM. } \\
\text { 192A, B \& C }\end{array}$ & $\mathrm{S}, \mathrm{C}, \mathrm{F}, \mathrm{X}, \mathrm{R}$ & $\begin{array}{l}\text { Safety Clas } \\
2,3,4,5\end{array}$ & $\begin{array}{l}\text { CRITICALITY } \\
\text { INTERNAL } \\
\text { FACILITY } \\
\text { RELEASE }\end{array}$ \\
\hline $\begin{array}{l}\text { INTERIOR WALL - WALLS \& CEILING } \\
\text { OF RM. 225 }\end{array}$ & $\mathrm{S}, \mathrm{C}, \mathrm{F}, \mathrm{R}, \mathrm{X}$ & $\begin{array}{l}\text { Safety Clas } \\
2,3,4,5\end{array}$ & $\begin{array}{l}\text { CRITICALITY } \\
\text { INTERNAL } \\
\text { FACILITY } \\
\text { RELEASE }\end{array}$ \\
\hline $\begin{array}{l}\text { INTERIOR WALL - EAST, WEST, \& } \\
\text { NORTH WALL OF RM. 227 }\end{array}$ & $\mathrm{F}, \mathrm{X}$ & $\begin{array}{l}\text { Safety Clas } \\
2,3,5\end{array}$ & $\begin{array}{l}\text { BREACH OF } \\
\text { CONF INEMENT }\end{array}$ \\
\hline $\begin{array}{l}\text { INTERIOR WALL - WEST WALL OF RMS. } \\
\text { 234 \& 234A }\end{array}$ & $\mathrm{X}$ & $\begin{array}{l}\text { Safety Clas } \\
2,3,5\end{array}$ & $\begin{array}{l}\text { BREACH OF } \\
\text { CONF INEMENT }\end{array}$ \\
\hline
\end{tabular}


DEFINITION AND MEANS OF MAINTAINING THE STRUCTURAL

CONFINEMENT FEATURES PORTION OF THE PFP SAFETY ENVELOPE
HNF-SD-CP-SDD-007

Rev. 1

Page 62 of 77

Table E.2. 234-5Z Building, First Floor (Page 3 of 3 ).

\begin{tabular}{||l|l|l|l|}
\hline \multicolumn{1}{|c|}{ COMPONENT } & FUNCTION & \multicolumn{1}{|c|}{$\begin{array}{l}\text { SAFETY CLASS/ } \\
\text { SURVIVAL }\end{array}$} & \multicolumn{1}{|c|}{$\begin{array}{c}\text { CONSEQUENCE } \\
\text { MITIGATED }\end{array}$} \\
\hline \hline $\begin{array}{l}\text { INTERIOR WALL - NORTH WALL } \\
\text { OF RM. 236 }\end{array}$ & $5, X, Z$ & $\begin{array}{l}\text { Safety Class } \\
2,3,5\end{array}$ & $\begin{array}{l}\text { BREACH OF } \\
\text { CONF INEMENT }\end{array}$ \\
\hline $\begin{array}{l}\text { INTERIOR WALL - COLUMN LINE } \\
\text { Ga, 19 to 21 (WALL } \\
\text { SEPARATING THE OFFICE ANNEX } \\
\text { FROM THE MAIN BLDG) }\end{array}$ & $\mathrm{E}$ & $\begin{array}{l}\text { Safety ClasS } \\
1,2,3,4,5,6,7\end{array}$ & $\begin{array}{l}\text { ENVIRONMENTAL } \\
\text { RELEASE }\end{array}$ \\
\hline
\end{tabular}


Table E.3. 234-5Z Duct Level

\begin{tabular}{|c|c|c|c|}
\hline CONPONENT & FUNCTION & $\begin{array}{c}\text { SAFETY CLASS/ } \\
\text { SURVIVAL }\end{array}$ & $\begin{array}{l}\text { CONSEQUENCE } \\
\text { MITIGATED }\end{array}$ \\
\hline $\begin{array}{l}\text { EXTERIOR WALLS - EXCEPT } \\
\text { 192A VAULT WALLS }\end{array}$ & $E, Z$ & $\begin{array}{l}\text { Safety } \mathrm{Cl} \text { ass } \\
1,2,3,4,5,6,7\end{array}$ & $\begin{array}{l}\text { ENVIRONMENTAL } \\
\text { RELEASE }\end{array}$ \\
\hline $\begin{array}{l}\text { CONCRETE EXTERIOR WALLS - } \\
\text { OF RM. } 192 A\end{array}$ & $E, C, S$ & $\begin{array}{l}\text { Safety } C] \text { ass } \\
1,2,3,4,5,6,7\end{array}$ & $\begin{array}{l}\text { ENVIRONMENTAL } \\
\text { RELEASE } \\
\text { CRITICALITY }\end{array}$ \\
\hline $\begin{array}{l}\text { CONCRETE INTERIOR WALLS - } \\
\text { OF RM. } 192 \mathrm{~A}\end{array}$ & $x, c, S$ & $\begin{array}{l}\text { Safety Class } \\
2,3,5\end{array}$ & $\begin{array}{l}\text { BREACH OF } \\
\text { CONFINEMENT } \\
\text { CRITICALITY } \\
\end{array}$ \\
\hline $\begin{array}{l}\text { INTERIOR WALLS - STAIR } 1 \text { - } \\
\text { CONCRETE WALLS }\end{array}$ & $S, I, F$ & $\begin{array}{l}\text { Safety } \mathrm{Cl} \text { ass } \\
2,3,5\end{array}$ & $\begin{array}{l}\text { BREACH OF } \\
\text { CONF INEMENT }\end{array}$ \\
\hline $\begin{array}{l}\text { INTERIOR WALLS - STAIR } 2 \text { - } \\
\text { CONCRETE WALLS }\end{array}$ & $\mathrm{S}, \mathrm{I}, \mathrm{F}$ & $\begin{array}{l}\text { Safety Class } \\
2,3,5\end{array}$ & $\begin{array}{l}\text { BREACH OF } \\
\text { CONF INEMENT }\end{array}$ \\
\hline $\begin{array}{l}\text { INTERIOR WALLS - CONCRETE } \\
\text { ELEVATOR SHAFT }\end{array}$ & $S, F$ & $\begin{array}{l}\text { Safety Class } \\
2,3,5\end{array}$ & $\begin{array}{l}\text { BREACH OF } \\
\text { CONF INEMENT }\end{array}$ \\
\hline $\begin{array}{l}\text { INTERIOR WALL - COLUMN C4 } \\
\text { TO C } 21\end{array}$ & $S, X, Z$ & $\begin{array}{l}\text { Safety Class } \\
2,3,5\end{array}$ & $\begin{array}{l}\text { BREACH OF } \\
\text { CONF INEMENT }\end{array}$ \\
\hline $\begin{array}{l}\text { INTERIOR WALL - COLUMN D8 } \\
\text { TO D } 17.5\end{array}$ & $S$ & $\begin{array}{l}\text { Safety } C 1 \text { ass } \\
2,3,5\end{array}$ & $\begin{array}{l}\text { BREACH OF } \\
\text { CONF INEMENT }\end{array}$ \\
\hline $\begin{array}{l}\text { INTERIOR WALL - COLUMN E4 } \\
\text { TO E21 }\end{array}$ & $S$ & $\begin{array}{l}\text { Safety Class } \\
2,3,5\end{array}$ & $\begin{array}{l}\text { BREACH OF } \\
\text { CONF INEMENT }\end{array}$ \\
\hline $\begin{array}{l}\text { INTERIOR WALL - EAST WALL } \\
\text { OF RM. } 263(\mathrm{C} 4 \text { TO E4) }\end{array}$ & $s, x$ & $\begin{array}{l}\text { Safety Class } \\
2,3,5\end{array}$ & $\begin{array}{l}\text { BREACH OF } \\
\text { CONF INEMENT }\end{array}$ \\
\hline
\end{tabular}


DEFINITION AND MEANS OF MAINTAINING THE STRUCTURAL

CONFINEMENT FEATURES PORTION OF THE PFP SAFETY ENVELOPE
HNF-SD-CP-SDD-007

Rev. 1

Page 64 of 77

Table E.4. 234-5Z Mezzanine Level, Column 8 Mezzanine and Column 7 0verpass.

\begin{tabular}{||c|l|l|l||}
\hline \multicolumn{1}{|c|}{ COMPONENT } & \multicolumn{1}{|c|}{ FUNCTION } & $\begin{array}{l}\text { SAFETY CLASS/ } \\
\text { SURVIVAL }\end{array}$ & \multicolumn{1}{|c|}{$\begin{array}{c}\text { CONSEQUENCE } \\
\text { MITIGATED }\end{array}$} \\
\hline $\begin{array}{l}\text { INTERIOR WALL - NORTH WALL OF } \\
\text { RM. 229 }\end{array}$ & $\mathrm{S}, \mathrm{X}$ & $\begin{array}{l}\text { Safety ClaSS } \\
2,3,5\end{array}$ & $\begin{array}{l}\text { BREACH OF } \\
\text { CONF INEMENT }\end{array}$ \\
\hline
\end{tabular}


DEFINITION AND MEANS OF MAINTAINING THE STRUCTURAL

CONFINEMENT FEATURES PORTION OF THE PFP SAFETY ENVELOPE
HNF-SD-CP-SDD-007

Rev. 1

Page 65 of 77

Table E.5. 234-5ż Mezzanine Level, Column 12 to Column 19 Mezzanine.

\begin{tabular}{||l|l|l|l||}
\hline \multicolumn{1}{|c|}{ COMPONENT } & \multicolumn{1}{|c||}{ FUNCIION } & $\begin{array}{l}\text { SAFETY CLASS/ } \\
\text { SURVIVAL }\end{array}$ & \multicolumn{1}{|c||}{$\begin{array}{c}\text { CONSEQUENCE } \\
\text { MITIGATED }\end{array}$} \\
\hline EXTERIOR WALL - COLUMN LINE 23 & $\mathrm{E}$ & $\begin{array}{l}\text { Safety Class } \\
1,2,3,4,5,6,7\end{array}$ & $\begin{array}{l}\text { ENVIRONMENTAL } \\
\text { RELEASE }\end{array}$ \\
\hline $\begin{array}{l}\text { INTERIOR WALL - COLUMN C12 T0 } \\
\text { COLUMN C19 }\end{array}$ & $\mathrm{X}, \mathrm{S}, \mathrm{Z}$ & $\begin{array}{l}\text { Safety Class } \\
2,3,5\end{array}$ & $\begin{array}{l}\text { BREACH OF } \\
\text { CONFINEMENT }\end{array}$ \\
\hline $\begin{array}{l}\text { INTERIOR WALL - COLUMN D12 T0 } \\
\text { COLUMN D17.5 }\end{array}$ & $\mathrm{X}, \mathrm{S}$ & $\begin{array}{l}\text { Safety ClasS } \\
2,3,5\end{array}$ & $\begin{array}{l}\text { BREACH OF } \\
\text { CONFINEMENT }\end{array}$ \\
\hline $\begin{array}{l}\text { INTERIOR WALL - COLUMN E12 T0 } \\
\text { COLUMN 21.5 }\end{array}$ & $\mathrm{X}, \mathrm{S}$ & $\begin{array}{l}\text { Safety ClasS } \\
2,3,5\end{array}$ & $\begin{array}{l}\text { BREACH OF } \\
\text { CONFINEMENT }\end{array}$ \\
\hline
\end{tabular}


DEFINITION AND MEANS OF MAINTAINING THE STRUCTURAL

CONFINEMENT FEATURES PORTION OF THE PFP SAFETY ENVELOPE
HNF-SD-CP-SDD-007

Rev. 1

Page 66 of 77

Table E.6. 234-5Z Building, Second Floor

\begin{tabular}{|c|c|c|c|}
\hline COMPONENT & FUNCTION & $\begin{array}{c}\text { SAFETY CLASS / } \\
\text { SURVIVAL }\end{array}$ & $\begin{array}{l}\text { CONSEQUENCE } \\
\text { MITIGATED }\end{array}$ \\
\hline EXTERIOR WALLS & $E$ & $\begin{array}{l}\text { Safety Class } \\
1,2,3,4,5,6,7\end{array}$ & $\begin{array}{l}\text { ENV IRONMENTAL } \\
\text { RELEASE } \\
\end{array}$ \\
\hline CONCRETE WALLS - STAIR 1 & $S, I, F$ & $\begin{array}{l}\text { Safety Class } \\
2,3,5\end{array}$ & $\begin{array}{l}\text { BREACH OF } \\
\text { CONF INEMENT }\end{array}$ \\
\hline CONCRETE WALLS - STAIR 2 & $S, I, F$ & $\begin{array}{l}\text { Safety class } \\
2,3,5\end{array}$ & $\begin{array}{l}\text { BREACH OF } \\
\text { CONF INEMENT } \\
\end{array}$ \\
\hline CONCRETE WALLS - ELEVATOR & $S, F$ & $\begin{array}{l}\text { Safety Class } \\
2,3,5\end{array}$ & $\begin{array}{l}\text { BREACH OF } \\
\text { CONF INEMENT }\end{array}$ \\
\hline $\begin{array}{l}\text { INTERIOR WALLS - INCLUDES RMS. } \\
309,310,311,312,313,314 \\
315,316 \& 318\end{array}$ & $\mathrm{X}, \mathrm{F}, \mathrm{Z}$ & $\begin{array}{l}\text { Safety Class } \\
3,5\end{array}$ & $\begin{array}{l}\text { BREACH OF } \\
\text { CONF INEMENT }\end{array}$ \\
\hline $\begin{array}{l}\text { INTERIOR WALLS -WALLS \& CEILING } \\
\text { OF RM. } 334 \text { \& } 335 \text { (Ca Storage } \\
\text { drives these rooms to Safety } \\
\text { Class; with out Ca Storage they } \\
\text { are Safety Significant) }\end{array}$ & $\begin{array}{l}F(\text { only } \\
\text { with } \\
\text { Ca), } x, Z\end{array}$ & $\begin{array}{l}\text { Safety Class } \\
3,5,6\end{array}$ & $\begin{array}{l}\text { BREACH OF } \\
\text { CONFINEMENT } \\
\text { (With out Ca } \\
\text { Internal } \\
\text { Facility } \\
\text { Release) }\end{array}$ \\
\hline
\end{tabular}


Table E.7. 234-5Z Building, Roof.

\begin{tabular}{||l|l|l|l||}
\hline \multicolumn{1}{|c|}{ COMPONENT } & FUNCTION & $\begin{array}{l}\text { SAFETY CLASS/ } \\
\text { SURVIVAL }\end{array}$ & $\begin{array}{l}\text { CONSEQUENCE } \\
\text { MITIGATED }\end{array}$ \\
\hline ROOF LINE WALL - A12 T0 D12 & $\mathrm{E}, \mathrm{Z}$ & $\begin{array}{l}\text { Safety Class } \\
1,2,3,5,6,7\end{array}$ & $\begin{array}{l}\text { ENVIRONMENTAL } \\
\text { RELEASE }\end{array}$ \\
\hline ROOF LINE WALL - D7 T0 D12 & $\mathrm{E}, \mathrm{Z}$ & $\begin{array}{l}\text { Safety Class } \\
1,2,3,5,6,7\end{array}$ & $\begin{array}{l}\text { ENVIRONMENTAL } \\
\text { RELEASE }\end{array}$ \\
\hline ROOF LINE WALL - D7 T0 G7 & $\mathrm{E}, \mathrm{Z}$ & $\begin{array}{l}\text { Safety Class } \\
1,2,3,5,6,7\end{array}$ & $\begin{array}{l}\text { ENVIRONMENTAL } \\
\text { RELEASE }\end{array}$ \\
\hline ROOF LINE WALL - F19 T0 G19 & $\mathrm{E}, \mathrm{Z}$ & $\begin{array}{l}\text { Safety Class } \\
1,2,3,5,6,7\end{array}$ & $\begin{array}{l}\text { ENVIRONMENTAL } \\
\text { RELEASE }\end{array}$ \\
\hline ROOF LINE WALL - F19 T0 F23 & $\mathrm{E}, \mathrm{Z}$ & $\begin{array}{l}\text { Safety Class } \\
1,2,3,5,6,7\end{array}$ & $\begin{array}{l}\text { ENVIRONMENTAL } \\
\text { RELEASE }\end{array}$ \\
\hline STAIR 1 CONCRETE WALLS \& ROOF & $\mathrm{S}$ & $\begin{array}{l}\text { Safety Class } \\
1,2,3,5,6,7\end{array}$ & $\begin{array}{l}\text { BREACH OF } \\
\text { CONF INEMENT }\end{array}$ \\
\hline
\end{tabular}


DEFINITION AND MEANS OF MAINTAINING THE STRUCTURAL

CONFINEMENT FEATURES PORTION OF THE PFP SAFETY ENVELOPE
HNF-SD-CP-SDD-007

Rev. 1

Page 68 of 77

Table E.8. 234-5Z Building, Foundation and Tunnels.

\begin{tabular}{||l|l|l|l||}
\hline \multicolumn{1}{|c|}{ COMPONENT } & FUNCTION & $\begin{array}{l}\text { SAFETY CLASS/ } \\
\text { SURVIVAL }\end{array}$ & \multicolumn{1}{|c|}{$\begin{array}{c}\text { CONSEQUENCE } \\
\text { MITIGATED }\end{array}$} \\
\hline ALL CONCRETE WALLS & $S, Z$ & $\begin{array}{l}\text { Safety Class } \\
1,2,3,5,6,7\end{array}$ & $\begin{array}{l}\text { BREACH OF } \\
\text { CONF INEMENT }\end{array}$ \\
\hline ALL FOOTINGS & $\mathrm{S}$ & $\begin{array}{l}\text { Safety C1 as S } \\
1,2,6,7\end{array}$ & $\begin{array}{l}\text { BREACH 0F } \\
\text { CONF INEMENT }\end{array}$ \\
\hline
\end{tabular}


DEFINITION AND MEANS OF MAINTAINING THE STRUCTURAL

CONFINEMENT FEATURES PORTION OF THE PFP SAFETY ENVELOPE
HNF-SD-CP-SDD-007

Rev. 1

Page 69 of 77

Table E.9. 236-Z Building, First Floor.

\begin{tabular}{|c|c|c|c|}
\hline COMPONENT & FUNCTION & $\begin{array}{l}\text { SAFETY CLASS/ } \\
\text { SURVIVAL }\end{array}$ & $\begin{array}{l}\text { CONSEQUENCE } \\
\text { MITIGATED }\end{array}$ \\
\hline EXTERIOR WALLS & $E, F, Z$ & $\begin{array}{l}\text { Safety Class } \\
1,2,3,4,5,6,7\end{array}$ & $\begin{array}{l}\text { ENVIRONMENTAL } \\
\text { RELEASE }\end{array}$ \\
\hline STAIR 1 & $S, F, X$ & $\begin{array}{l}\text { Safety Class } \\
1,2,3,5\end{array}$ & $\begin{array}{l}\text { BREACH OF } \\
\text { CONFINEMENT }\end{array}$ \\
\hline STAIR 2 & $S, F, X, I$ & $\begin{array}{l}\text { Safety Class } \\
1,2,3,5\end{array}$ & $\begin{array}{l}\text { BREACH OF } \\
\text { CONF INEMENT }\end{array}$ \\
\hline ELEVATOR SHAFT WALLS & $S, F, X$ & $\begin{array}{l}\text { Safety Class } \\
2,3,5\end{array}$ & $\begin{array}{l}\text { BREACH OF } \\
\text { CONFINEMENT }\end{array}$ \\
\hline INTERIOR WALL - EAST CANYON WALL & $\mathrm{S}, \mathrm{X}, \mathrm{R}$ & $\begin{array}{l}\text { Safety class } \\
2,3,4,5\end{array}$ & $\begin{array}{l}\text { BREACH OF } \\
\text { CONFINEMENT }\end{array}$ \\
\hline INTERIOR WALL - WEST CANYON WALL & $S, X, R$ & $\begin{array}{l}\text { Safety class } \\
2,3,4,5\end{array}$ & $\begin{array}{l}\text { BREACH OF } \\
\text { CONF INEMENT }\end{array}$ \\
\hline $\begin{array}{l}\text { INTERIOR WALL - CORR. } 10 \text { SOUTH } \\
\text { WALL TO COLUMN } 3\end{array}$ & $S, X, R$ & $\begin{array}{l}\text { Safety Class } \\
2,3,5\end{array}$ & $\begin{array}{l}\text { BREACH OF } \\
\text { CONF INEMENT }\end{array}$ \\
\hline $\begin{array}{l}\text { INTERIOR WALL - CORRIDOR } 14 \text { EAST } \\
\text { WALL }\end{array}$ & $S, X$ & $\begin{array}{l}\text { Safety Class } \\
2,3,5\end{array}$ & $\begin{array}{l}\text { BREACH OF } \\
\text { CONF INEMENT }\end{array}$ \\
\hline $\begin{array}{l}\text { INTERIOR WALL - RM. } 16 \& 17 \\
\text { NORTH WALL }\end{array}$ & $S, x$ & $\begin{array}{l}\text { Safety Class } \\
2,3,5\end{array}$ & $\begin{array}{l}\text { BREACH OF } \\
\text { CONFINEMENT }\end{array}$ \\
\hline $\begin{array}{l}\text { INTERIOR WALL - RM. } 19 \text { NORTH, } \\
\text { WEST, \& SOUTH WALLS }\end{array}$ & $s, x$ & $\begin{array}{l}\text { Safety Class } \\
2,3,5\end{array}$ & $\begin{array}{l}\text { BREACH OF } \\
\text { CONFINEMENT }\end{array}$ \\
\hline
\end{tabular}


DEFINITION AND MEANS OF MAINTAINING THE STRUCTURAL

CONFINEMENT FEATURES PORTION OF THE PFP SAFETY ENVELOPE
HNF-SD-CP-SDD-007

Rev. 1

Page 70 of 77

Table E.10. 236-Z Building, Second Floor.

\begin{tabular}{|c|c|c|c|}
\hline COMPONENT & FUNCTION & $\begin{array}{c}\text { SAFETY CLASS/ } \\
\text { SURVIVAL }\end{array}$ & $\begin{array}{l}\text { CONSEQUENCE } \\
\text { MITIGATED }\end{array}$ \\
\hline EXTERIOR WALLS & $E, S$ & $\begin{array}{l}\text { Safety C1ass } \\
1,2,3,4,5,6,7\end{array}$ & $\begin{array}{l}\text { ENVIRONMENTAL } \\
\text { RELEASE }\end{array}$ \\
\hline STAIR 1 & $S, F, X$ & $\begin{array}{l}\text { Safety Class } \\
1,2,3,5\end{array}$ & $\begin{array}{l}\text { BREACH OF } \\
\text { CONFINEMENT }\end{array}$ \\
\hline STAIR 2 & $S, I, F, X$ & $\begin{array}{l}\text { Safety Class } \\
1,2,3,5\end{array}$ & $\begin{array}{l}\text { BREACH OF } \\
\text { CONF INEMENT }\end{array}$ \\
\hline ELEVATOR SHAFT WALLS & $S, F, X$ & $\begin{array}{l}\text { Safety Class } \\
2,3,5\end{array}$ & $\begin{array}{l}\text { BREACH OF } \\
\text { CONF INEMENT }\end{array}$ \\
\hline INTERIOR WALL - CANYON WALLS & $R, X, S$ & $\begin{array}{l}\text { Safety Class } \\
2,3,4,5\end{array}$ & $\begin{array}{l}\text { BREACH OF } \\
\text { CONF INEMENT }\end{array}$ \\
\hline $\begin{array}{l}\text { INTERIOR WALL - EAST WALL OF } \\
\text { CORR } 25\end{array}$ & $S, X$ & $\begin{array}{l}\text { Safety Class } \\
2,3,5\end{array}$ & $\begin{array}{l}\text { BREACH OF } \\
\text { CONFINEMENT }\end{array}$ \\
\hline $\begin{array}{l}\text { INTERIOR WALL - NORTH WALL OF } \\
\text { RM. } 26\end{array}$ & $\mathrm{~S}$ & $\begin{array}{l}\text { Safety Class } \\
2,3,5\end{array}$ & $\begin{array}{l}\text { BREACH OF } \\
\text { CONF INEMENT }\end{array}$ \\
\hline $\begin{array}{l}\text { ELEVATOR - SOUTHWEST CORNER OF } \\
\text { RM. } 27 \text { TO NORTH WALL OF RM. } 26 \\
\end{array}$ & $\mathrm{~S}$ & $\begin{array}{l}\text { Safety Class } \\
2,3,5\end{array}$ & $\begin{array}{l}\text { BREACH OF } \\
\text { CONF INEMENT }\end{array}$ \\
\hline $\begin{array}{l}\text { INTERIOR WALL - NORTH \& SOUTH } \\
\text { WALL OF RM. } 27\end{array}$ & S & $\begin{array}{l}\text { Safety class } \\
2,3,5\end{array}$ & $\begin{array}{l}\text { BREACH OF } \\
\text { CONF INEMENT }\end{array}$ \\
\hline
\end{tabular}


Table E.11. 236-z Building, Third Floor.

\begin{tabular}{|c|c|c|c|}
\hline CONPONENT & FUNCTION & $\begin{array}{l}\text { SAFETY CLASS/ } \\
\text { SURVIVAL }\end{array}$ & $\begin{array}{l}\text { CONSEQUENCE } \\
\text { MITIGATED } \\
\end{array}$ \\
\hline EXTERIOR WALLS & $E, S$ & $\begin{array}{l}\text { Safety Class } \\
1,2,3,4,5,6,7\end{array}$ & $\begin{array}{l}\text { ENV IRONMENTAL } \\
\text { RELEASE }\end{array}$ \\
\hline STAIR 1 - CONCRETE WALLS & $S, F, X$ & $\begin{array}{l}\text { Safety Class } \\
1,2,3,5\end{array}$ & $\begin{array}{l}\text { BREACH OF } \\
\text { CONFINEMENT }\end{array}$ \\
\hline STAIR 2 - CONCRETE WALLS & $S, I, F, E$ & $\begin{array}{l}\text { Safety Class } \\
1,2,3,5\end{array}$ & $\begin{array}{l}\text { BREACH OF } \\
\text { CONFINEMENT }\end{array}$ \\
\hline ELEVATOR SHAFT WALLS & $S, F, X$ & $\begin{array}{l}\text { Safety Class } \\
2,3,5\end{array}$ & $\begin{array}{l}\text { BREACH OF } \\
\text { CONF INEMENT } \\
\end{array}$ \\
\hline $\begin{array}{l}\text { INTERIOR WALL - CANYON CONCRETE } \\
\text { WALLS }\end{array}$ & $S, X, R$ & $\begin{array}{l}\text { Safety Class } \\
2,3,4,5\end{array}$ & $\begin{array}{l}\text { BREACH OF } \\
\text { CONF INEMENT }\end{array}$ \\
\hline CONCRETE DUCT WALLS & $\mathrm{S}, \mathrm{F}, \mathrm{X}$ & $\begin{array}{l}\text { Safety Class } \\
2,3,5\end{array}$ & $\begin{array}{l}\text { BREACH OF } \\
\text { CONFINEMENT }\end{array}$ \\
\hline CORRIDOR 33 EAST WALL & $S$ & $\begin{array}{l}\text { Safety class } \\
2,3,5\end{array}$ & $\begin{array}{l}\text { BREACH OF } \\
\text { CONFINEMENT }\end{array}$ \\
\hline $\begin{array}{l}\text { INTERIOR WALL - WEST WALL OF } \\
\text { RM. } 35 \text { \& WEST DOORS OF RM. } 34\end{array}$ & $S$ & $\begin{array}{l}\text { Safety Class } \\
2,3,5\end{array}$ & $\begin{array}{l}\text { BREACH OF } \\
\text { CONFINEMENT }\end{array}$ \\
\hline WALL BETWEEN RMS. $36 \& 38$ & $\mathrm{~S}$ & $\begin{array}{l}\text { Safety Class } \\
2,3,5\end{array}$ & $\begin{array}{l}\text { BREACH OF } \\
\text { CONFINEMENT }\end{array}$ \\
\hline
\end{tabular}


Table E.12. 236-Z Building, Fourth Floor.

\begin{tabular}{|c|c|c|c|}
\hline COMPONENT & FUNCTION & $\begin{array}{l}\text { SAFETY CLASS/ } \\
\text { SURVIVAL }\end{array}$ & $\begin{array}{c}\text { CONSEQUENCE } \\
\text { MITIGATED }\end{array}$ \\
\hline EXTERIOR WALLS & $\mathrm{E}, \mathrm{S}$ & $\begin{array}{l}\text { Safety Class } \\
1,2,3,4,5,6,7\end{array}$ & $\begin{array}{l}\text { ENV IRONMENTAL } \\
\text { RELEASE }\end{array}$ \\
\hline CONCRETE WALLS - STAIR 1 & $S, F, X$ & $\begin{array}{l}\text { Safety Class } \\
2,3,5\end{array}$ & $\begin{array}{l}\text { BREACH OF } \\
\text { CONFINEMENT }\end{array}$ \\
\hline CONCRETE WALLS - STAIR 2 & $S, I, S, X$ & $\begin{array}{l}\text { Safety class } \\
2,3,5\end{array}$ & $\begin{array}{l}\text { BREACH OF } \\
\text { CONFINEMENT }\end{array}$ \\
\hline $\begin{array}{l}\text { CONCRETE WALLS - ELEVATOR } \\
\text { SHAFT }\end{array}$ & $S, F, X$ & $\begin{array}{l}\text { Safety Class } \\
2,3,5\end{array}$ & $\begin{array}{l}\text { BREACH OF } \\
\text { CONF INEMENT }\end{array}$ \\
\hline $\begin{array}{l}\text { INTERIOR WALL - NORTH \& EAST } \\
\text { WALLS OF RM. } 42\end{array}$ & $S, X$ & $\begin{array}{l}\text { Safety } \mathrm{Cl} \text { ass } \\
2,3,4,5\end{array}$ & $\begin{array}{l}\text { BREACH OF } \\
\text { CONF INEMENT }\end{array}$ \\
\hline $\begin{array}{l}\text { INTERIOR WALL - EAST WALL OF } \\
\text { CORR. } 47 \& \text { RM. } 43\end{array}$ & $\mathrm{~S}$ & $\begin{array}{l}\text { Safety Class } \\
2,3,5\end{array}$ & $\begin{array}{l}\text { BREACH OF } \\
\text { CONF INEMENT }\end{array}$ \\
\hline ROOF & $\mathrm{E}$ & $\begin{array}{l}\text { Safety Class } \\
1,2,3,4,5,6,7\end{array}$ & $\begin{array}{l}\text { ENV IRONMENTAL } \\
\text { RELEASE }\end{array}$ \\
\hline
\end{tabular}


Table E.13. 236-Z Building, Fifth Floor.

\begin{tabular}{||l|l|l|l||}
\hline \multicolumn{1}{|c|}{ COMPONENT } & FUNCTION & \multicolumn{1}{|c|}{$\begin{array}{l}\text { SAFETY CLASS/ } \\
\text { SURVIVAL }\end{array}$} & \multicolumn{1}{|c|}{$\begin{array}{c}\text { CONSEQUENCE } \\
\text { MITIGATED }\end{array}$} \\
\hline EXTERIOR WALLS & $\mathrm{E}, \mathrm{S}$ & $\begin{array}{l}\text { Safety Clas } \\
1,2,3,4,5,6,7\end{array}$ & $\begin{array}{l}\text { ENVIRONMENTAL } \\
\text { RELEASE }\end{array}$ \\
\hline CONCRETE WALLS - STAIR 2 & $\mathrm{S}, \mathrm{F}, \mathrm{X}, 1$ & $\begin{array}{l}\text { Safety C1 as } \\
1,2,3,5,6,7\end{array}$ & $\begin{array}{l}\text { BREACH OF } \\
\text { CONFINEMENT }\end{array}$ \\
\hline
\end{tabular}

Table E.14. 236-Z Building, Sixth Floor.

\begin{tabular}{||l|l|l|l||}
\hline \multicolumn{1}{|c|}{ COMPONENT } & FUNCTION & \multicolumn{1}{|c|}{$\begin{array}{c}\text { SAFETY CLASS/ } \\
\text { SURVIVAL }\end{array}$} & $\begin{array}{c}\text { CONSEQUENCE } \\
\text { MITIGATED }\end{array}$ \\
\hline EXTERIOR WALLS & $E, S$ & $\begin{array}{l}\text { Safety Class } \\
1,2,3,4,5,6,7\end{array}$ & $\begin{array}{l}\text { ENVIRONMENTAL } \\
\text { RELEASE }\end{array}$ \\
\hline CONCRETE WALLS - STAIR 2 & $E, F, X, I$ & $\begin{array}{l}\text { Safety Class } \\
1,2,3,4,5,6,7\end{array}$ & $\begin{array}{l}\text { BREACH OF } \\
\text { CONF INEMENT }\end{array}$ \\
\hline ROOF & $E$ & $\begin{array}{l}\text { Safety Class } \\
1,2,3,4,5,6,7\end{array}$ & $\begin{array}{l}\text { ENVIRONMENTAL } \\
\text { RELEASE }\end{array}$ \\
\hline
\end{tabular}


Table E.15. 2736-ZB Building, First Floor.

\begin{tabular}{||l|l|l|l||}
\hline \multicolumn{1}{|c|}{ COMPONENT } & FUNCTION & $\begin{array}{l}\text { SAFETY CLASS/ } \\
\text { SURVIVAL }\end{array}$ & $\begin{array}{l}\text { CONSEQUENCE } \\
\text { MITIGATED }\end{array}$ \\
\hline EXTERIOR WALLS & $E, Z, S, F$ & $\begin{array}{l}\text { Safety Class } \\
1,2,3,5,6,7\end{array}$ & $\begin{array}{l}\text { ENVIRONMENTAL } \\
\text { RELEASE }\end{array}$ \\
\hline $\begin{array}{l}\text { INTERIOR WALL - EAST WALL OF } \\
\text { CORR. 625 }\end{array}$ & $S, X, F$ & $\begin{array}{l}\text { Safety Class } \\
2,3,5\end{array}$ & $\begin{array}{l}\text { BREACH OF } \\
\text { CONF INEMENT }\end{array}$ \\
\hline $\begin{array}{l}\text { INTERIOR WALL - EAST, SOUTH WALL } \\
\text { OF RM. 636 }\end{array}$ & $S, X, F$ & $\begin{array}{l}\text { Safety Class } \\
2,3,5\end{array}$ & $\begin{array}{l}\text { BREACH OF } \\
\text { CONFINEMENT }\end{array}$ \\
\hline $\begin{array}{l}\text { INTERIOR WALL - EAST, WEST, SOUTH } \\
\text { WALL OF RM. 637 }\end{array}$ & $S, X, F$ & $\begin{array}{l}\text { Safety Class } \\
2,3,5\end{array}$ & $\begin{array}{l}\text { BREACH OF } \\
\text { CONF INEMENT }\end{array}$ \\
\hline $\begin{array}{l}\text { ALL OTHER INTERIOR CONCRETE WALLS } \\
\text { R,F }\end{array}$ & $\begin{array}{l}\text { Safety Class } \\
2,3,5\end{array}$ & $\begin{array}{l}\text { BREACH OF } \\
\text { CONF INEMENT }\end{array}$ \\
\hline ROOF & $\mathrm{E}, \mathrm{Z}, \mathrm{S}$ & $\begin{array}{l}\text { Safety Class } \\
1,2,3,5,6,7\end{array}$ & $\begin{array}{l}\text { ENVIRONMENTAL } \\
\text { RELEASE }\end{array}$ \\
\hline
\end{tabular}

Table E.16. 2736-Z Building.

\begin{tabular}{||l|l|l|l||}
\hline \multicolumn{1}{|c|}{ COMPONENT } & \multicolumn{1}{|c|}{ FUNCTION } & $\begin{array}{l}\text { SAFETY CLASS/ } \\
\text { SURVIVAL }\end{array}$ & $\begin{array}{l}\text { CONSEQUENCE } \\
\text { MITIGATED }\end{array}$ \\
\hline EXTERIOR WALLS & $\mathrm{E}, \mathrm{C}, \mathrm{Z}, \mathrm{R}, \mathrm{S}$ & $\begin{array}{l}\text { Safety Class } \\
1,2,3,4,5,6,7\end{array}$ & $\begin{array}{l}\text { ENVIRONMENTAL } \\
\text { RELEASE } \\
\text { CRITICALITY }\end{array}$ \\
\hline $\begin{array}{l}\text { INTERIOR WALLS BETWEEN } \\
\text { VAULT 1 \& 2, AND 3 \& 4 }\end{array}$ & $\mathrm{C}, \mathrm{X}, \mathrm{R}, \mathrm{S}, \mathrm{F}$ & $\begin{array}{l}\text { Safety Class } \\
2,3,4,5\end{array}$ & $\begin{array}{l}\text { CRITICALITY } \\
\text { INTERNAL } \\
\text { FACILITY } \\
\text { RELEASE }\end{array}$ \\
\hline $\begin{array}{l}\text { CONCRETE WALLS BETWEEN } \\
\text { CORRIDOR AND VAULTS }\end{array}$ & $\mathrm{C}, \mathrm{X}, \mathrm{R}, \mathrm{F}, \mathrm{S}$ & $\begin{array}{l}\text { Safety ClasS } \\
2,3,4,5\end{array}$ & $\begin{array}{l}\text { CRITICALITY } \\
\text { INTERNAL } \\
\text { FACILITY } \\
\text { RELEASE }\end{array}$ \\
\hline ROOF & $\mathrm{E}, \mathrm{C}, \mathrm{Z}, \mathrm{S}$ & $\begin{array}{l}\text { Safety ClaSS } \\
1,2,3,4,5,6,7\end{array}$ & $\begin{array}{l}\text { ENVIRONMENTAL } \\
\text { RELEASE } \\
\text { CRITICALITY }\end{array}$ \\
\hline
\end{tabular}


Table E.17. 242-Z Building.

\begin{tabular}{|c|c|c|c|}
\hline COMPONENT & FUNCTION & $\begin{array}{c}\text { SAFETY CLASS/ } \\
\text { SURVIVAL }\end{array}$ & $\begin{array}{c}\text { CONSEQUENCE } \\
\text { MITIGATED }\end{array}$ \\
\hline $\begin{array}{l}\text { NORTH INTERIOR WALL - } \\
\text { (COLUMN Jl-J3) }\end{array}$ & $s, x$ & $\begin{array}{l}\text { Safety Class } \\
2,3\end{array}$ & $\begin{array}{l}\text { BREACH OF } \\
\text { CONFINEMENT }\end{array}$ \\
\hline $\begin{array}{l}\text { SOUTH INTERIOR WALL - } \\
\text { (COLUMN } 1-3 \text { NORTH WALL OF } \\
\text { CORRIDOR } 10 \text { ) }\end{array}$ & $s, x$ & $\begin{array}{l}\text { Safety Class } \\
2,3\end{array}$ & $\begin{array}{l}\text { BREACH OF } \\
\text { CONFINEMENT }\end{array}$ \\
\hline $\begin{array}{l}\text { EAST EXTERIOR WALL - } \\
\text { (COLUMN J1-DOOR } 11 \text { AT } \\
\text { COLUMN 1) }\end{array}$ & $\mathrm{E}, \mathrm{S}$ & $\begin{array}{l}\text { Safety } C 1 \text { ass } \\
1,2,3,6,7\end{array}$ & $\begin{array}{l}\text { ENV IRONMENTAL } \\
\text { RELEASE }\end{array}$ \\
\hline $\begin{array}{l}\text { WEST EXTERIOR WALL }-(\mathrm{J} 4 \\
\text { SOUTH TO CORRIDOR } 10 \text { NORTH } \\
\text { WALL) }\end{array}$ & $E, S$ & $\begin{array}{l}\text { Safety } C 1 \text { ass } \\
1,2,3,6,7\end{array}$ & $\begin{array}{l}\text { ENVIRONMENTAL } \\
\text { RELEASE }\end{array}$ \\
\hline $\begin{array}{l}\text { WEST INTERIOR WALL - } \\
\text { (COLUMN J3 S-DOOR } 13 \text { ) }\end{array}$ & $E, S$ & $\begin{array}{l}\text { Safety } C 1 \text { ass } \\
1,2,3,6,7\end{array}$ & $\begin{array}{l}\text { BREACH OF } \\
\text { CONFINEMENT }\end{array}$ \\
\hline ROOF & $E$ & $\begin{array}{l}\text { Safety } \mathrm{Cl} \text { ass } \\
1,2,3,6,7\end{array}$ & $\begin{array}{l}\text { ENV IRONMENTAL } \\
\text { RELEASE }\end{array}$ \\
\hline
\end{tabular}


Table E.18. 291-Z-1 Stack.

\begin{tabular}{||l|l|l|l||}
\hline COMPONENT & FUNCTION & \multicolumn{1}{|c|}{$\begin{array}{c}\text { SAFETY CLASS/ } \\
\text { SURVIVAL }\end{array}$} & \multicolumn{1}{|c|}{$\begin{array}{c}\text { CONSEQUENCE } \\
\text { MITIGATED }\end{array}$} \\
\hline FOUNDATION \& STACK & $\mathrm{S}$ & $\begin{array}{l}\text { Safety ClaSS } \\
1,2,5,6,7\end{array}$ & $\begin{array}{l}\text { POTENTIAL LOSS } \\
\text { OF OTHER } \\
\text { BUILDINGS }\end{array}$ \\
\hline
\end{tabular}

Table E.19. 232-Z Building.

\begin{tabular}{|c|c|c|c|}
\hline CONPONENT & FUNCTION & $\begin{array}{c}\text { SAFETY CLASS/ } \\
\text { SURVIVAL }\end{array}$ & $\begin{array}{c}\text { CONSEQUENCE } \\
\text { MITIGATED } \\
\end{array}$ \\
\hline EXTERIOR WALLS & $E, S, Z$ & $\begin{array}{l}\text { Safety } C 7 \text { ass } \\
1,2,3,5,6,7\end{array}$ & $\begin{array}{l}\text { ENV I RONMENTAL } \\
\text { RELEASE }\end{array}$ \\
\hline $\begin{array}{l}\text { INTERIOR WALLS BETWEEN } \\
\text { FILTER ROOM \& PROCESS } \\
\text { ROOM }\end{array}$ & $s, x$ & $\begin{array}{l}\text { Safety Class } \\
2,3,5\end{array}$ & $\begin{array}{l}\text { BREACH OF } \\
\text { CONF INEMENT }\end{array}$ \\
\hline $\begin{array}{l}\text { INTERIOR WALLS BETWEEN } \\
\text { PROCESS ROOM \& CHANGE } \\
\text { ROOM }\end{array}$ & $S, x$ & $\begin{array}{l}\text { Safety Class } \\
2,3,5\end{array}$ & $\begin{array}{l}\text { BREACH OF } \\
\text { CONF INEMENT }\end{array}$ \\
\hline $\begin{array}{l}\text { INTERIOR WALLS BETWEEN } \\
\text { CHEMICAL MIX ROOM AND } \\
\text { ELECTRICAL \& CHANGE ROOMS }\end{array}$ & $S$ & $\begin{array}{l}\text { Safety Class } \\
2,3,5\end{array}$ & $\begin{array}{l}\text { BREACH OF } \\
\text { CONF INEMENT }\end{array}$ \\
\hline RoOF & $E, Z$ & $\begin{array}{l}\text { Safety Class } \\
1,2,3,5,6,7\end{array}$ & $\begin{array}{l}\text { ENV I RONMENTAL } \\
\text { RELEASE } \\
\end{array}$ \\
\hline
\end{tabular}

Table E.20. 232-Z Building, Second Floor.

\begin{tabular}{|l|l|l|l||}
\hline \multicolumn{1}{|c|}{ COMPONENT } & \multicolumn{1}{|c||}{ FUNCTION } & \multicolumn{1}{|c|}{$\begin{array}{l}\text { SAFETY CLASS/ } \\
\text { SURVIVAL }\end{array}$} & \multicolumn{1}{c|}{$\begin{array}{c}\text { CONSEQUENCE } \\
\text { MITIGATED }\end{array}$} \\
\hline $\begin{array}{l}\text { EXTERIOR WALLS - HVAC } \\
\text { INCLUDES DUCT \& FAN RM. }\end{array}$ & $X$ & $\begin{array}{l}\text { Safety ClasS } \\
2,3,5\end{array}$ & $\begin{array}{l}\text { BREACH OF } \\
\text { CONFINEMENT }\end{array}$ \\
\hline
\end{tabular}




\section{E. 10 REFERENCES}

NFPA 101, 1991, Life Safety Code, National Fire Protection Association, Quincy, Massachusetts.

WHC, Plutonium Finishing Plant Final Safety Analysis Report, WHC-SD-CP-SAR-021, Rev. 0, Westinghouse Hanford Company, Richland, Washington. 